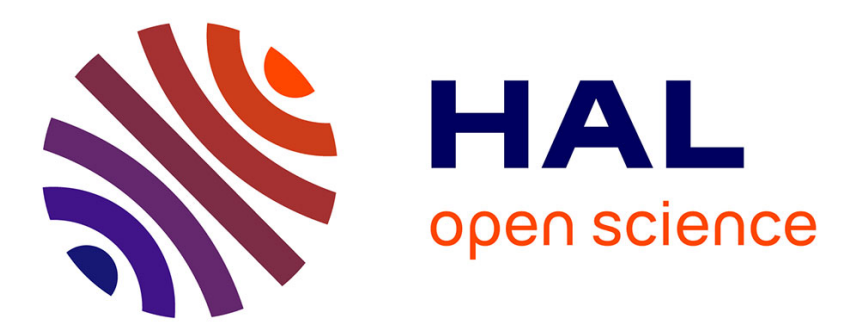

\title{
Using Monovalent- to Trivalent-Cation Hybrid Perovskites for Producing High-Efficiency Solar Cells: Electrical Response, Impedance, and Stability
} Daming Zheng, Tao Zhu, Thierry Pauporté

\section{- To cite this version:}

Daming Zheng, Tao Zhu, Thierry Pauporté. Using Monovalent- to Trivalent-Cation Hybrid Perovskites for Producing High-Efficiency Solar Cells: Electrical Response, Impedance, and Stability. ACS Applied Energy Materials, 2020, 10.1021/acsaem.0c00884 . hal-02999451

\section{HAL Id: hal-02999451 https://hal.science/hal-02999451}

Submitted on 10 Nov 2020

HAL is a multi-disciplinary open access archive for the deposit and dissemination of scientific research documents, whether they are published or not. The documents may come from teaching and research institutions in France or abroad, or from public or private research centers.
L'archive ouverte pluridisciplinaire HAL, est destinée au dépôt et à la diffusion de documents scientifiques de niveau recherche, publiés ou non, émanant des établissements d'enseignement et de recherche français ou étrangers, des laboratoires publics ou privés. 
Please cite this paper as:

D. Zheng, T. Zhu, Th. Pauporté, Using Monovalent- to Trivalent-Cation Hybrid Perovskites for Producing High-Efficiency Solar Cells: Electrical Response, Impedance, and Stability. ACS Appl. Energy Mater. (2020) DOI/10.1021/acsaem.0c00884

\title{
Mono- to Tri-Cation Hybrid Perovskites for High-Efficiency Solar Cells: Electrical Response, Impedance and Stability.
}

\author{
Daming Zheng, "Tao Zhu, ${ }^{\text {Thierry Pauporté* }}$
}

Chimie ParisTech, PSL Research University, CNRS, Institut de Recherche de Chimie Paris (IRCP), UMR8247, 11 rue P. et M. Curie, F-75005 Paris, France.

*Corresponding author, email: thierry.pauporte@chimieparistech.psl.eu

${ }^{\#}$ Both authors contributed equally to the work

\begin{abstract}
Solar cells based on Organometal halide perovskites have emerged recently as the most promising technology for high efficiency. During the last years, innovative film processings have been developed for increasing the devices performances and stability. The two most fruitful have been (i) to complexify the perovskite composition by mixing monovalent cations and (ii) to add additives in the precursor solution which are eliminated upon the film annealing and post-deposition processing step. In the present work, perovskite films varying in their monovalent cation content, from one to three $\left(\mathrm{MAPbI}_{3}, \mathrm{Cs}_{0.08} \mathrm{FA}_{0.80} \mathrm{MA}_{0.12} \mathrm{~Pb}\left(\mathrm{I}_{0.88} \mathrm{Br}_{0.12}\right)_{3}\right.$ and $\mathrm{FA}_{1-\mathrm{x}} \mathrm{MA}_{\mathrm{x}} \mathrm{PbI}_{3}$ ) and optimized to reach high efficiency up to $22.2 \%$ have been thoroughly compared for their steady-state and impedance electrical responses. Much information has been extracted from the electrical impedance spectroscopy data after their fitting by equivalent electrical circuits. With the help of complementary measurements (photoluminescence, scanning electron microscopy, $\mathrm{V}_{\mathrm{oc}}$ measurements...), the spectral features have been assigned
\end{abstract}




\section{Zheng, T. Zhu, Th. Pauporté ACS Appl. Energy Mater. (2020) DOI/10.1021/acsaem.0c00884}

to physical phenomena. The relative permittivities of MAPI, CsFAMA and FAMA have been extracted from the high-frequency capacitance $C_{2}$. The high-frequency resistance $R_{2}$ has been related to the slow lifetime of the time-resolved photoluminescence and assigned to the bulk recombination resistance of the perovskite. The low-frequency resistance $\mathrm{R}_{4}$ has been assigned to recombinations occurring at and near the interfaces. The Low-frequency capacitance $\mathrm{C}_{4}$ has been related to the $J$ - $V$ curves hysteresis and assigned to recombinations. Recombination in PSC is phase delayed due to the dynamics of ions and related defect formation. It induces an imaginary component in the impedance spectra that is analyzed as $\mathrm{C}_{4}$. Overall, the (ii) strategy of mediating the growth of $\mathrm{FA}_{1-\mathrm{x}} \mathrm{MA}_{\mathrm{x}} \mathrm{PbI}_{3}$ perovskite double cation by additive is found the best to suppress recombinations, suppress ion mobility, reach high efficiency with low hysteresis and stabilize the perovskite compound.

Keywords: Perovskite solar cells, Impedance spectroscopy, Mono- and Multi-cations, Recombination, Ionic mobility.

\section{Introduction}

Organic-inorganic hybrid perovskites (OIHP) mix both organic and inorganic components and have the $\mathrm{ABX}_{3}$ general formula, with $\mathrm{A}$ a monovalent cation, $\mathrm{B}$ a divalent metal cation and $\mathrm{X}$ a halide anion. They have emerged recently as a versatile and exciting class of semiconductor materials for applications in opto-electronics. ${ }^{1}$ These compounds combine the key properties of traditional inorganic semiconductors such as gallium arsenide (GaAs) and silicon ( $\mathrm{Si}$ ), including high charge carrier mobility and device efficiency, with the advantageous properties of organic semiconductors such as preparation simplicity, low-temperature processing, lowcost and property tunability. Impressive progresses have been made recently on the application of OIHPs in various fields such as lasers, ${ }^{2}$ LEDs, ${ }^{3}$ photodetectors, ${ }^{4}$ scintillators ${ }^{5}$ and photovoltaic solar cells. ${ }^{1,6-19}$ This material family exhibits excellent optoelectronic properties, an adjustable bandgap, long charge carrier diffusion length, ${ }^{20}$ low-cost and low-temperature solution processibility. ${ }^{1,20}$ OIHPs thin films can be printed on flexible substrates for lightweight devices. ${ }^{21}$ The certified present record efficiency for a PSC is $25.5 \% .^{22}$

The structural unit of OIHP compounds contains an anionic corner-sharing octahedral network stabilized by cations. The stability of the 3D perovskite phase is limited by geometry and oxidation state restrictions, quantified by a tolerance factor $\left(t_{f}\right)$. The well-known Goldsmith tolerance factor has been refined recently by Bartel et al. ${ }^{23}$ : 


$$
t_{f}=\frac{r_{x}}{r_{B}}-n_{A}\left(n_{A}-\frac{r_{A} / r_{B}}{\ln \left({ }^{\left.r_{A} / r_{B}\right)}\right)}\right.
$$

where $n_{A}$ is the oxidation state of $\mathrm{A}(+1), r_{i}$ is the ionic radius of ion i $(2.70 \AA$ for methyl ammonium (MA), $2.79 \AA$ for formamidinium (FA), $1.81 \AA$ for $\mathrm{Cs}$ and $1.19 \AA$ for $\left.\mathrm{Pb}^{2+}\right), \mathrm{r}_{\mathrm{A}}>\mathrm{r}_{\mathrm{B}}$ by definition. $t_{f}<4.18$ indicates that the perovskite structure is allowed. MA and FA are the two main organic monovalent cations that can be employed as organic A. However, due to the large size of FA, increasing the complexity of the perovskite was proved necessary to increase the PSC stability and performances. ${ }^{24-26}$ Above the pioneering popular monovalent mono-cation $\mathrm{MAPbI}_{3}$ compound, a huge research effort has been directed towards the development of double-cation $\mathrm{FA}_{1-\mathrm{x}} \mathrm{MA}_{\mathrm{x}} \mathrm{PbX}_{3}$ and triple-cation $\mathrm{M}_{\mathrm{y}}^{\mathrm{a}}\left(\mathrm{FA}_{1-\mathrm{x}} \mathrm{MA}_{\mathrm{x}}\right) \mathrm{PbX}_{3}$ (with $\mathrm{M}^{\mathrm{a}}$ an alkali metal) perovskites to improve the device performances and stability. In the latter case, Cs is the most popular elemental monovalent cation incorporated. However, the full entropic stabilization of this triple cation perovskite also requires the addition of $\mathrm{Br}$ in complement to I for $\mathrm{X}^{24}$

Alternative strategies of stabilization by using additives have been developed lately ${ }^{6,27}$ and, to get stable double cation perovskite, we have developed recently the use of $\mathrm{MACl}$ as an additive in the $\mathrm{FA}_{1-\mathrm{x}} \mathrm{MA}_{\mathrm{x}} \mathrm{PbI}_{3}$ precursor solution. ${ }^{6}$ This compound has allowed the direct deposition of the perovskite phase upon the spin-coating and then the growth of well-crystalized $\mathrm{FA}_{1-\mathrm{x}} \mathrm{MA}_{\mathrm{x}} \mathrm{PbI}_{3}$ layers upon the annealing post-deposition step.

The purpose of the present paper is to investigate the electrical response, especially the electrical impedance spectra, of high efficiency PSCs. The perovskite composition has been varied, especially the number of monovalent cation employed to stabilized the perovskite photoactive phase. Based on this compositional study and the literature data, we propose a better understanding of the main features found in their impedance spectra and provide an answer to the question: what are the expected impedance spectra for the best PSCs? More precisely, we compare the following perovskites: $\mathrm{MAPbI}_{3}, \quad \mathrm{FA}_{0.94} \mathrm{MA}_{0.06} \mathrm{PbI}_{3}$ and $\mathrm{Cs}_{0.08} \mathrm{FA}_{0.80} \mathrm{MA}_{0.12} \mathrm{~Pb}\left(\mathrm{I}_{0.88} \mathrm{Br}_{0.12}\right)_{3}$. They have been the subject of a thorough optimization work in the group for the last years. ${ }^{6,28}$ The best performances were achieved for the second one at $22.2 \%$. The basic electrical characterization of a PSC just consists in measuring their $J-V$ curves in the reverse and forward scan directions and in quantifying the hysteresis amplitude. However, it provides poor information about the dynamic processes occurring in the cells. In the present work, these measurements have been completed by an investigation of the effect of light intensity on the steady-state $V_{o c}$ and by impedance spectroscopy measurements. The 


\section{Zheng, T. Zhu, Th. Pauporté ACS Appl. Energy Mater. (2020) DOI/10.1021/acsaem.0c00884}

former provides information and quantifications about the recombination mechanism. The latter gives an in-depth and complete view of the physical phenomena occurring in PSCs in operation. With the help of complementary measurements, the spectral features have been assigned to physical phenomena. The various relaxations have been decomposed and quantified using electrical elements. Their variation has been analyzed with the applied voltage and the chemical nature of the perovskite. The present comparative study has allowed us to clarify the assignment of some electrical elements and to confirm others. Moreover, we have attached a special attention to the stability of the systems under irradiation and electrical stresses since these measurements provide a good quantification of the PSC stability. ${ }^{11}$

\section{Experimental}

The Fluorine-doped $\mathrm{SnO}_{2}$ (FTO) substrates (TEC 7 from Pilkington) were etched, patterned and a compact $\mathrm{TiO}_{2}$ layer $\left(c-\mathrm{TiO}_{2}\right)$ was deposited by spray pyrolysis as detailed in our Ref. ${ }^{18}$. A mesoporous $\mathrm{TiO}_{2}$ layer $\left(m p-\mathrm{TiO}_{2}\right)$ was subsequently prepared by spin-coating as described in our Ref. ${ }^{28,29}$.

MAPI layers preparation: A 1.45 M MAPI precursor solution was prepared by mixing 668.5 $\mathrm{mg} \mathrm{PbI}_{2}$ and $230.5 \mathrm{mg} \mathrm{MAI}$ in $1 \mathrm{ml}$ DMSO. The solution was stirred and kept warm at $100^{\circ} \mathrm{C}$ for $2 \mathrm{~h}$ before use. The spin-coating program was $1000 \mathrm{rpm}$ for $10 \mathrm{~s}$ and $6000 \mathrm{rpm}$ for $30 \mathrm{~s} .100$ $\mu \mathrm{L}$ of chlorobenzene was dripped $30 \mathrm{~s}$ after the starting of the spinning routine. The layers were finally annealed on a hotplate at $105^{\circ} \mathrm{C}$ for $60 \mathrm{~min}$. The best performances were achieved after the device preparation. These layers are denoted MAPI throughout the paper.

CSFAMA layers preparation: A precursor solution corresponding to a $\mathrm{Cs}_{0.08} \mathrm{FA}_{0.80} \mathrm{MA}_{0.12} \mathrm{~Pb}\left(\mathrm{I}_{0.88} \mathrm{Br}_{0.12}\right)_{3}$ perovskite layer composition was prepared. First, $179 \mathrm{mg}$ of formamidinium iodide (FAI), $17.4 \mathrm{mg}$ of methylammonium bromide (MABr), $27.0 \mathrm{mg}$ of CsI, $548 \mathrm{mg}$ of $\mathrm{PbI}_{2}$ and $57.1 \mathrm{mg}$ of $\mathrm{PbBr}_{2}$ were mixed in $220 \mu \mathrm{L}$ DMSO and $780 \mu \mathrm{L} \mathrm{DMF}$. The solution was stirred for a minimum of 3-4 $\mathrm{h}$ at room temperature in a $\mathrm{N}_{2}$ filled glovebox before use. ${ }^{29,30,31} 45 \mu \mathrm{L}$ of this solution was placed on top of the substrates. A two-step spin-coating program was employed: first spinning at $1000 \mathrm{rpm}$ for $10 \mathrm{~s}$ and then at $6000 \mathrm{rpm}$ for $30 \mathrm{~s} .100$ $\mu \mathrm{L}$ of chlorobenzene was dripped $20 \mathrm{~s}$ after the starting of the spinning routine. The films were then annealed at $105{ }^{\circ} \mathrm{C}$ for $1 \mathrm{~h}$ in a dry atmosphere. The best performances and smallest 


\section{Zheng, T. Zhu, Th. Pauporté ACS Appl. Energy Mater. (2020) DOI/10.1021/acsaem.0c00884}

hysteresis index (HI) were achieved after 7-8 days of storage in the $\mathrm{N}_{2}$ filled glovebox. These layers are denoted CsFAMA throughout the paper.

FAMA layers preparation: A mixed cation precursor solution with a $1.2 \mathrm{M}$ concentration was prepared by mixing $206 \mathrm{mg}$ of formamidinium iodide (FAI, greatcell), $553 \mathrm{mg}$ of $\mathrm{PbI}_{2}$ (TCI), and $38.9 \mathrm{mg}$ of methylammonium chloride (MACl, Alfa aesar) in $800 \mu \mathrm{L}$ DMF and $200 \mu \mathrm{L}$ DMSO. The solutions were stirred for a minimum of $2 \mathrm{~h}$ at room temperature in a nitrogen filled glovebox. $45 \mu \mathrm{L}$ of this solution was placed on top of the substrates. A two-step spin-coating program was run: first spinning at $1000 \mathrm{rpm}$ for $10 \mathrm{~s}$ and then at $6000 \mathrm{rpm}$ for $30 \mathrm{~s} .100 \mu \mathrm{L}$ of chlorobenzene was dripped $20 \mathrm{~s}$ after the starting of the spinning routine. The films were then annealed at $153{ }^{\circ} \mathrm{C}$ for $13 \mathrm{~min}$. The PEAI post-deposition treatment consisted in dropping 60 $\mu \mathrm{L}$ of a $10 \mathrm{mM}$ 2-Phenylethylamine Hydroiodide (PEAI) solution $(2.49 \mathrm{mg}$ in $1 \mathrm{~mL}$ of isopropanol) onto the perovskite film after cooling. A one-step spin-coating program was employed: $2000 \mathrm{rpm} / \mathrm{s}$ acceleration, 3000rpm for 20s. The best performances and smallest HI were achieved after 3-4 days of storage in the $\mathrm{N}_{2}$ filled glovebox. These $\mathrm{FA}_{1-\mathrm{x}} \mathrm{MA}_{\mathrm{x}} \mathrm{PbI}_{3}$ layers are denoted FAMA throughout the paper.

The Spiro-OMeTAD hole transporting layer (HTL) was spin-coated on the top of the perovskite layers and a 70-80 nm thick gold back contact was thermally evaporated on the HTL as detailed in Ref. $^{29}$ (see section A of the Supporting Information).

The sample morphologies were examined with a high resolution Ultra 55 Zeiss FEG fieldemission scanning electron microscope (FE-SEM) in the in-lens mode. The time-resolved photoluminescence (TRPL) measurements were performed through a microscope lens (numerical aperture 0.7 ). The perovskites layers were spin-coated onto a glass/FTO/c- $-\mathrm{TiO}_{2} / m p$ $\mathrm{TiO}_{2}$ substrate. The top of the OIHP layers was excited by a $470 \mathrm{~nm}$ diode laser (Picoquant) and the emission was filtered by a 488-nm longpass filter. It was analyzed for time-resolved photoluminescence decay, by a PerkinElmer SPCM avalanche photodiode combined with a Picoharp acquisition card ( $500 \mathrm{ps}$ characteristic time of the total system response function) used with the laser in a pulsed mode at a $10 \mathrm{nW}$ excitation power (pulse duration $70 \mathrm{ps}$ ).

The $J-V$ curves were recorded by a Keithley 2410 digital sourcemeter, using a $0.1 \mathrm{~V} . \mathrm{s}^{-1}$ voltage scan rate. ${ }^{32}$ The solar cells were illuminated with a solar simulator (Abet Technology Sun 2000) equipped with a xenon lamp, which light was filtered to mimic AM 1.5G conditions $\left(100 \mathrm{~mW} / \mathrm{cm}^{2}\right) .{ }^{32}$ The illuminated surface was delimited by a black mask with an aperture diameter of $3 \mathrm{~mm}$. The power density was calibrated at $100 \mathrm{~mW} . \mathrm{cm}^{-2}$ by the use of a reference 


\section{Zheng, T. Zhu, Th. Pauporté ACS Appl. Energy Mater. (2020) DOI/10.1021/acsaem.0c00884}

silicon solar cell. ${ }^{33}$ The electrical impedance spectra of the PSCs were measured in air, at room temperature and ambient humidity $(\sim 4 \%<\mathrm{RH}<\sim 60 \%)$. A PGSTAT 12 apparatus from Autolab was employed. The frequency ranged between $1 \mathrm{MHz}$ and $20 \mathrm{mHz}$, the ac signal amplitude was $20 \mathrm{mV}$. All the measured solar cells were unencapsulated and had the same contact geometries. The impedance spectra were measured at room temperature, over a large applied voltage $\left(V_{a p p l}\right)$ range, under $\sim 90 \mathrm{~mW} / \mathrm{cm}^{2}$ light power density irradiation supplied by a halogen Schott lamp equipped with an optical fiber light guide. The cell illuminated area was delimited by a $0.16 \mathrm{~cm}^{2}$ mask. The full recording of the spectra and characterization of a cell lasted about $1 \mathrm{~h}$. The spectra were analyzed using the Z-view software from National Instrument.

\section{Results and discussion}

\subsection{Perovskites characterizations.}

The morphology of the three different perovskite films as revealed by SEM is disclosed in Figure 1. Top views show their poly-crystallinity and that they are made of merged crystal grains. The crystal grain size analysis and distribution were performed using the Image $\mathbf{J}$ software (Figure 1d). In the MAPI layer, they had an average size of $410 \mathrm{~nm}$ (Figure 1a). The layers were well-covering. The CsFAMA layers were made of smaller crystal grains with an average size of $160 \mathrm{~nm}$ (Figure 1b). They were compact, uniform with no pinholes. The bright grains observed on the surface have been assigned to $\mathrm{PbI}_{2}$ by EDX analysis. The FAMA layers were nicely compact, uniform and made of remarkably large crystal grains. Their average size was measured at $1020 \mathrm{~nm}$ (Figure 1c). The formation of large grains is due to the use of a chloride additive (MACl) in the precursor solution. Chloride is known to favor the growth of well-crystallized layers. ${ }^{33-37}$ In summary, using mixed cation precursor produces more compact layers while the presence of a chloride additive mediates the growth of the perovskite and produces large grains. 

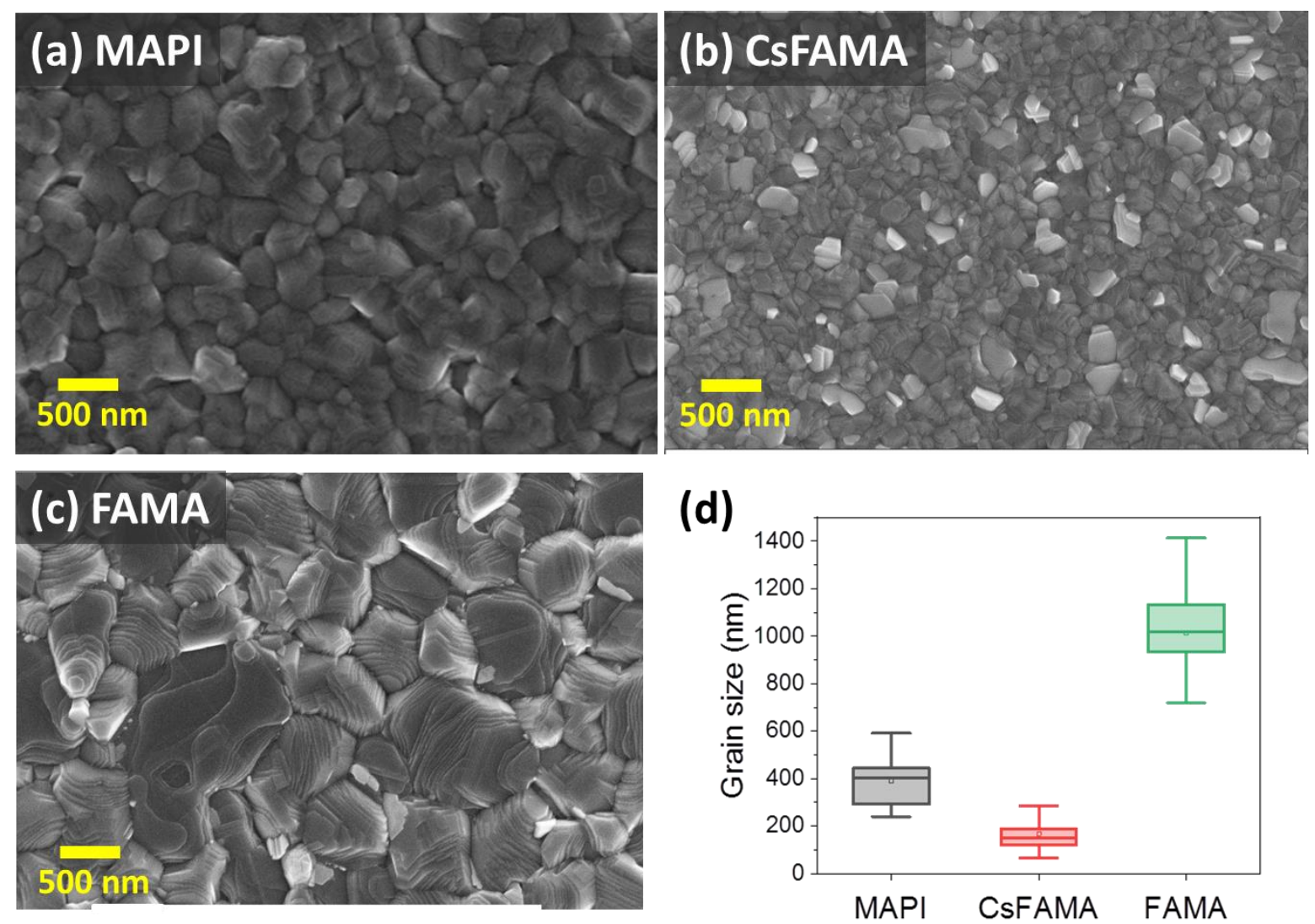

Figure 1. SEM top-views of the perovkite layers investigated. (a) MAPI, (b) CsFAMA and (c) FAMA. (d) Grain size statistical analysis of the perovskite layers.

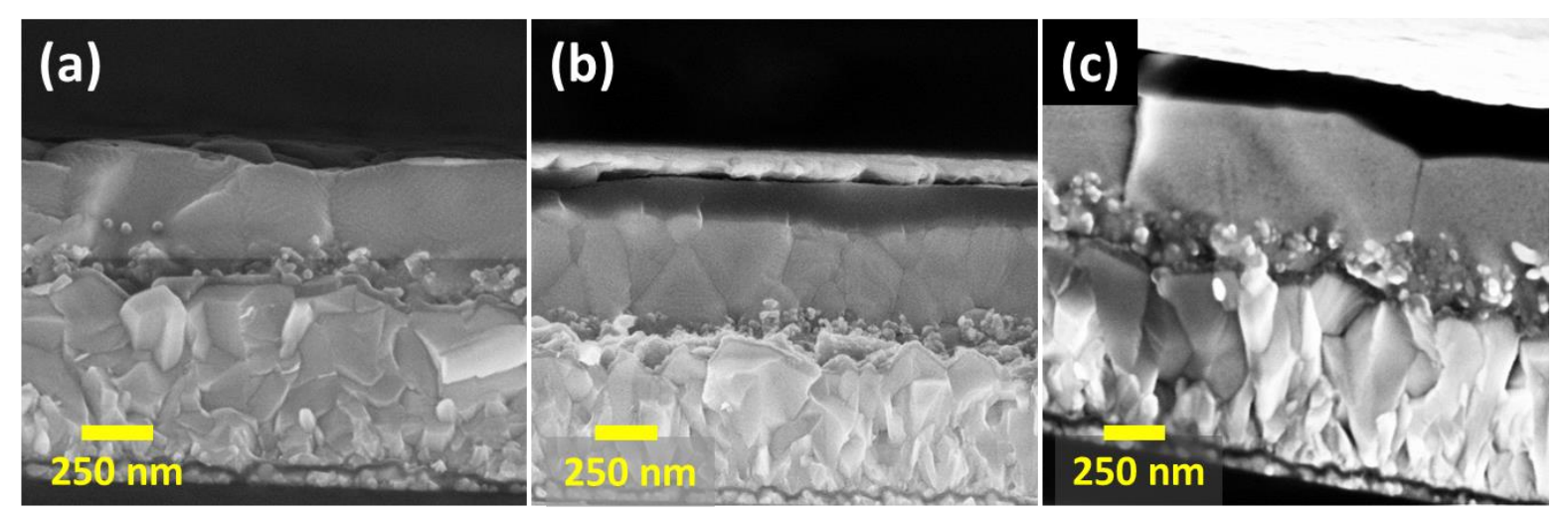

Figure 2. SEM cross-sectional views of the perovskite layers. (a) MAPI, (b) CsFAMA and (c) FAMA.

Further information on the layers morphology was gained from SEM cross-sectional images of the perovskite films (Figure 2). They confirmed that the CsFAMA layer had the smallest grains (Figure 2b). The images of the FAMA layer in Figure 2c shows remarkably monolithic large crystal grains. The interesting point is that they extend through the entire perovskite layer 
thickness and that each large crystal is contacted on one side by $\mathrm{TiO}_{2}$ and, on the other side, by Spiro-OMeTAD. This ideal morphology contrasts with the CsFAMA film one where many grain boundaries are present in the layer bulk. Therefore, under light irradiation, the charges photogenerated in CsFAMA layers can encounter grain boundaries, be trapped and recombined there, before to be collected. The layers thicknesses were evaluated from the SEM views and found to be $360-380 \mathrm{~nm}, 440-460 \mathrm{~nm}$ and 410-430 nm for MAPI, CsFAMA and FAMA, respectively.

Detailed structural, compositional and optical characterizations of the layers are provided in the Supporting Information (Section B). Briefly, XRD patterns revealed that the three samples were well-crystallized (Figure S1, Supporting Information). MAPI and FAMA layers were phase pure with no $\mathrm{PbI}_{2}$. Traces of $\mathrm{PbI}_{2}$ were present in the CsFAMA layer. The elemental analysis by EDX and ${ }^{1} \mathrm{H}-\mathrm{NMR}$ investigations ${ }^{6}$ provided the compositions: $\mathrm{MAPbI}_{3}$, $\mathrm{Cs}_{0.08} \mathrm{FA}_{0.80} \mathrm{MA}_{0.12} \mathrm{~Pb}\left(\mathrm{I}_{0.88} \mathrm{Br}_{0.12}\right)_{3}$ and $\mathrm{FA}_{0.94} \mathrm{MA}_{0.06} \mathrm{PbI}_{3}$ for MAPI, CsFAMA and FAMA samples, respectively (Supporting Information). The full optical characterizations reported in the Supporting Information show a high absorbance for the FAMA layer. The optical bandgap $\left(E_{g}\right)$ is smaller for FAMA $(1.53 \mathrm{eV})$ compared to MAPI and CsFAMA $(1.59 \mathrm{eV})$. For the latter compound the presence of bromide enlarges $E_{g}$. A consequence is the higher PL emission wavelength for FAMA (812 nm) compared to MAPI and CsFAMA (775 nm).

\subsection{Perovskite solar cells performances}

The architecture of the perovskite solar cells is presented in Figure 3a. The $J$ - $V$ curves are shown in Figure 3b and Figure $\mathbf{S 3}$ (Supporting Information) and the $J-V$ curve parameters of the best cells are gathered in Table 1. The maximum power conversion efficiency (PCE) of MAPI cell achieved $18.93 \%$, stabilized at $18.65 \%$. It was $20.36 \%$, stabilized at $20.03 \%$ for CsFAMA cells. We have demonstrated elsewhere that the intercalation of a 4-Chlorobenzoic acid self-assembled monolayer at the $\mathrm{TiO}_{2} / \mathrm{CsFAMA}$ interface boosts the performance to $21.35 \% .{ }^{29}$ MAPI and CsFAMA compounds have the same $E_{g}$, however, CsFAMA cells present a higher $J_{s c}$ and $V_{o c}$. The former is mainly due to a higher absorbance (Figure S2a, Supporting Information) and absence of pinholes. Defects in the MAPI layer can result in recombination pathways between holes and electrons that lower the FF and $V_{o c}$ parameters. The better $V_{o c}$ of CsFAMA cells is assigned to less recombinations occurring in the bulk and at the interfaces. 
The FAMA cells exhibited the highest efficiency. The PCE could reach a remarkable 22.18 $\%$ value and the stabilized PCE achieved $22.08 \%$. $J_{s c}$ was boosted due to a wider wavelength range for the light-harvesting (Figure S2, Supporting Information) and to the high structural quality and big grains. These cells also presented the best FF. The lower bandgap is at the origin of the lower $\mathrm{V}_{\mathrm{oc}}$ of the FAMA cells compared to the CsFAMA ones. All the trends obtained for the best cells were confirmed by the statistical analysis disclosed in Figure 4a.

(a)

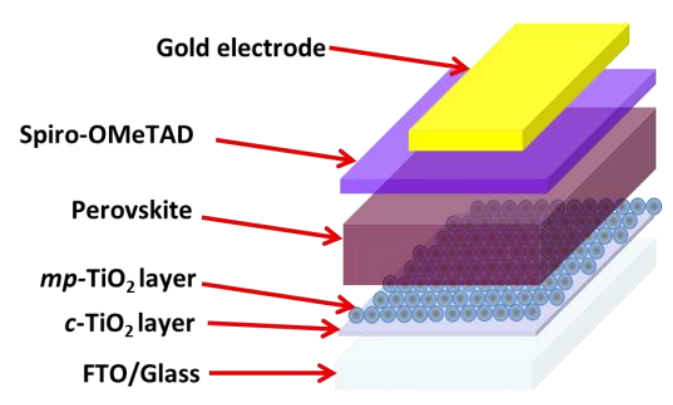

(b) $\quad 287$

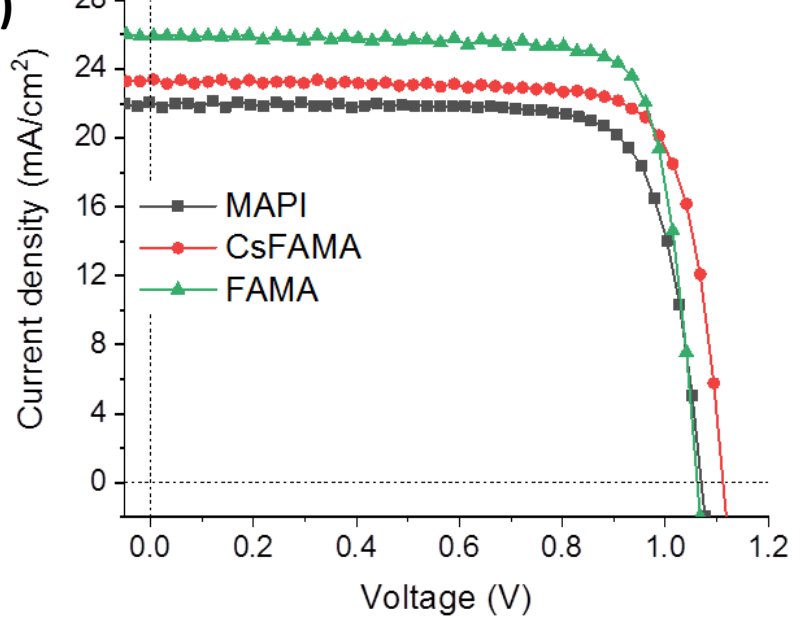

Figure 3. (a) Exploded schematic view of the perovskite solar cells. (b) Reverse $J$ - $V$ curves of MAPI, CsFAMA and FAMA cells.

Table 1. Typical photovoltaic $J-V$ parameters of cells among the best.

\begin{tabular}{|c|c|c|c|c|c|c|c|}
\hline Sample & $\begin{array}{l}\text { Scan } \\
\text { direction }\end{array}$ & $V_{o c} / V$ & $\begin{array}{l}J_{s c} \\
m A / c m\end{array}$ & $\mathrm{FF} / \%$ & $P C E / \%$ & $\begin{array}{l}\text { Stabilized } \\
P C E^{a} / \%\end{array}$ & $H I^{b} / \%$ \\
\hline \multirow{2}{*}{ MAPI } & Reverse & 1.063 & 23.08 & 77.43 & 18.93 & \multirow{2}{*}{18.65} & \multirow{2}{*}{6.5} \\
\hline & Forward & 1.059 & 22.51 & 73.99 & 17.70 & & \\
\hline \multirow{2}{*}{ CsFAMA } & Reverse & 1.110 & 23.13 & 79.27 & 20.36 & \multirow{2}{*}{20.03} & \multirow{2}{*}{6.1} \\
\hline & Forward & 1.101 & 23.13 & 75.00 & 19.10 & & \\
\hline \multirow{2}{*}{ FAMA } & Reverse & 1.060 & 25.94 & 80.62 & 22.18 & \multirow{2}{*}{22.08} & \multirow{2}{*}{3.7} \\
\hline & Forward & 1.052 & 25.93 & 78.26 & 21.35 & & \\
\hline
\end{tabular}

${ }^{\text {a }}$ Measured by tracking at the maximum power point.

${ }^{\mathrm{b}} \mathrm{HI}:$ Hysteresis index defined as: $\left[\mathrm{PCE}(\%)_{\mathrm{rev}}-\mathrm{PCE}(\%)_{\mathrm{for}}\right] / \mathrm{PCE}(\%)_{\mathrm{rev}}$ 


\section{Zheng, T. Zhu, Th. Pauporté ACS Appl. Energy Mater. (2020) DOI/10.1021/acsaem.0c00884}

We also noted that the HI parameter is similar for the MAPI and the CsFAMA cells with values of ca 6-7\% for the best cells. On average, it was $11-14 \%$ for MAPI and 6-8 \% for CsFAMA cells. This parameter was significantly better in the case of the FAMA cells with reproducible and remarkably low values at only $3-4 \%$.

(a)
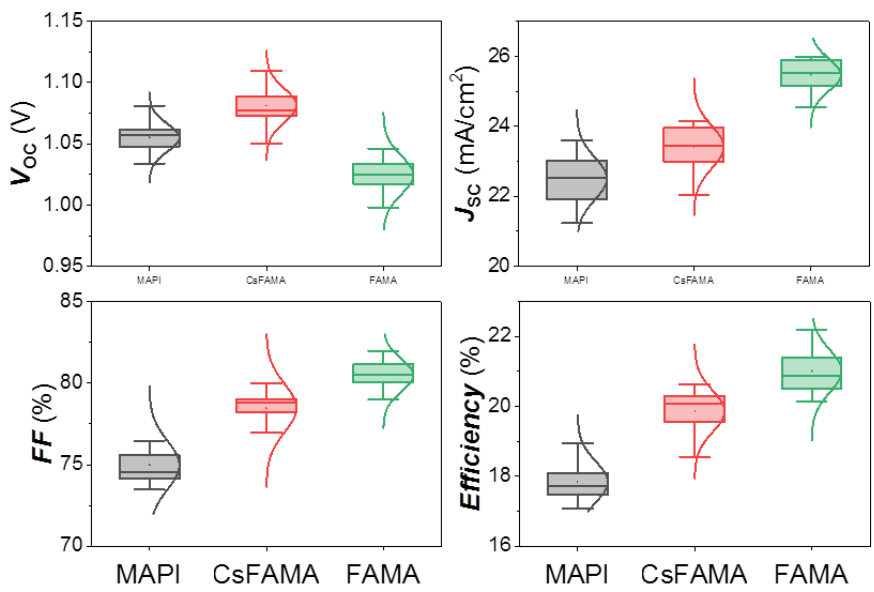

(b)

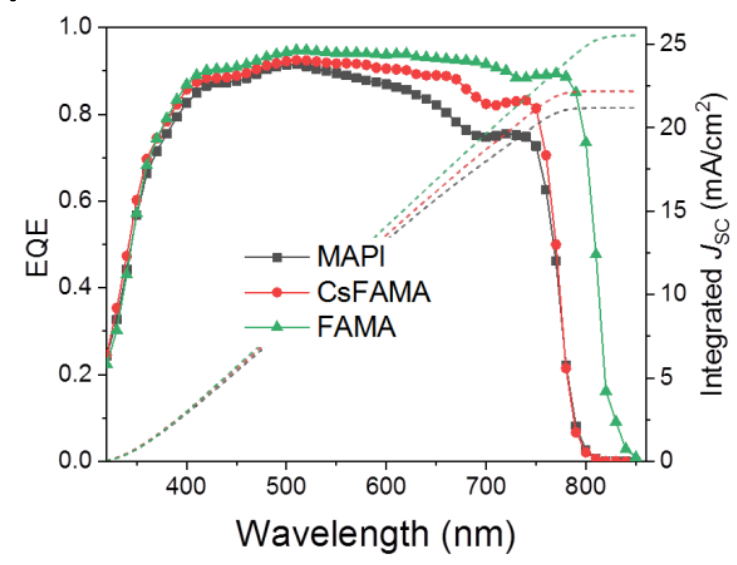

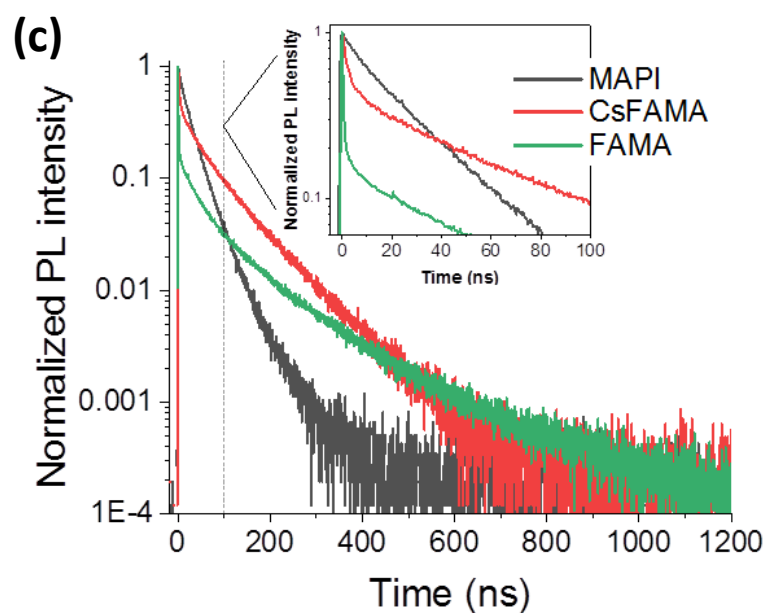

Figure 4. (a) Statistical analysis of the PSCs performances and $J$ - $V$ curves parameters. (b) EQE spectra of the three perovskites with the integrated $J_{s c}$ curves. (c) TRPL curves. The inset is a zoom view at short times.

The ability of the PSCs to collect light and to generate charge with a high efficiency was studied by measuring their EQE spectra (Figure 4b). MAPI cells presented the lowest performances, especially at high wavelengths, for which the irradiation penetration depth is the longest. The integration of the spectra gave a $J_{s c}$ of $21.1 \mathrm{~mA} \cdot \mathrm{cm}^{-2}$. For the CsFAMA cell, the charge generation edge was similar but the EQE was higher compared to MAPI. The integration gave a $J_{s c}$ of $22.2 \mathrm{~mA} . \mathrm{cm}^{-2}$. Using the FAMA perovskite produced two major effects: firstly, it 
shifted the charge generation edge toward higher wavelengths at about $820 \mathrm{~nm}$, in good agreement with the absorbance spectra of Figure S2 (Supporting Information); secondly, a high efficiency of $90 \%$ or above was achieved in the full visible and near-IR range. The integration of the spectrum provided a calculated $J_{s c}$ of $25.5 \mathrm{~mA} . \mathrm{cm}^{-2}$ in good agreement with the $J-V$ measurements. Further information on the charge collection was extracted from TRPL experiments. In Figure 4c, at short times zoomed in the inset, CsFAMA and FAMA had a similar behavior. They presented a fast decay with characteristic times at $2.0 \mathrm{~ns}$ and $0.5 \mathrm{~ns}$, respectively (Table S2, Supporting Information). The amplitude of the decay was markedly higher for FAMA compared to CsFAMA. The fast component is assigned to the non-radiative recombinations of the charges that are injected into $\mathrm{TiO}_{2} \cdot{ }^{38}$ Our results show that the charge injection is faster and more efficient for FAMA compared to CsFAMA. For MAPI perovskite, the first decay component was much slower at $27 \mathrm{~ns}$. It is the main relative contribution to the decay (75\%) (Table S2, Supporting Information). It suggests that in the case of MAPI, the electron injection towards $\mathrm{TiO}_{2}$ is slower and more difficult in agreement with the lower EQE found (Figure 4b).

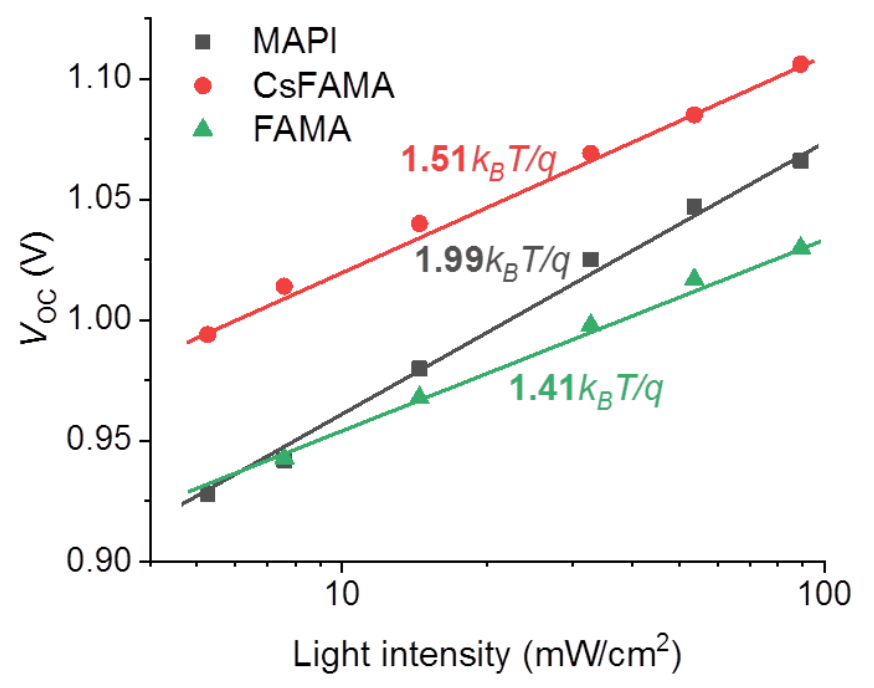

Figure 5. Variation of $V_{o c}$ as a function of the light power density. The curve slopes provide the ideality factor values ( $n_{\mathrm{ID}}$, numbers in bold).

We measured the cells $V_{o c}$ under various continuous light power densities (I). A white light source was employed and the curves are disclosed in Figure 5. CsFAMA cells presented a 
superior $V_{O C}$ over all the investigated light intensity range. The $V_{O C}$ scaled logarithmically with $I$ and followed the relationship:

$$
q V_{O C}=\mathrm{E}_{\mathrm{g}}+n_{\mathrm{ID}} k T \ln \left(I / I_{0}\right)
$$

with $q$ the elementary charge, $k$ the Boltzmann constant, $T$ the absolute temperature and $n_{\mathrm{ID}}$ the ideality factor. The latter parameter was determined from the curve fits. It is related to the main recombination phenomena occurring at the $V_{o c}{ }^{39}$ In classical semiconductor theory, a value of 1 for this parameter indicates a band-to-band recombination. ${ }^{39,40}$ Deviation of $n_{\mathrm{ID}}$ from 1 to 2 reflects the occurrence of trap-assisted Shockley-Read-Hall (SRH) recombination through perovskite intragap defects. ${ }^{39}$ The higher is $n_{\mathrm{ID}}$, the higher is the SRH recombination processes. $n_{\mathrm{ID}}$ was the lowest for FAMA at $\sim 1.4$ which had a superior quality compared to CsFAMA ( $n_{\mathrm{ID}}$ $\sim 1.5$ ), and especially compared to MAPI ( $n_{\mathrm{ID}} \sim 2.0$ ) (Figure 5). SRH recombination increases from FAMA, CsFAMA and MAPI. However, we will see below that, in PSCs, interfacial recombination always occurs and must be taken into account. Figure 5 illustrates that for an optimized functioning over a large light power density, the $n_{\mathrm{ID}}$ parameter must be the lower.

\subsection{Impedance spectroscopy}

The electrical response of the cells has been in-depth investigated by electrical impedance spectroscopy (EIS), a technique which provides in operando characterizations and is safe for the devices. ${ }^{8,11,18,19,40-60}$ By sweeping the frequency over a wide range, the various electrical phenomena occurring in the PSCs at various time scales can be discriminated. To have a comprehensive overview of the electrical response and well-understand the $J$ - $V$ curves, we have measured spectra under illumination with an applied voltage $\left(V_{\text {appl }}\right)$ varied from the short circuit to the open circuit. This technique provides a deep understanding of the devices functioning. 

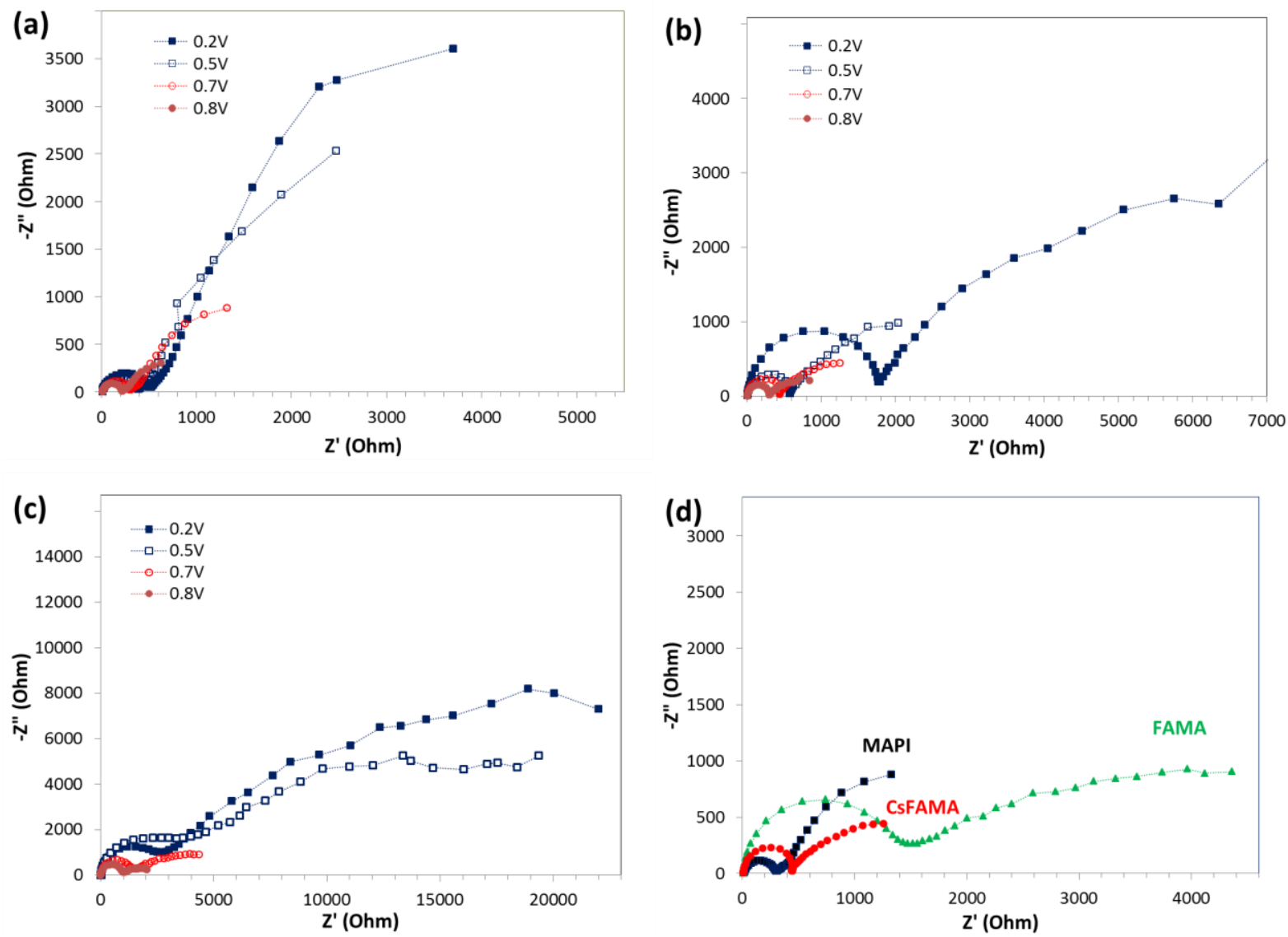

Figure 6. Impedance spectra of the investigated PSCs under illumination. Effect of the applied voltage for (a) MAPI, (b) CsFAMA and (c) FAMA. (d) Comparison of the EIS at $0.7 \mathrm{~V}$ for the three cells.

Figure 6 shows the effect of $\mathrm{V}_{\text {appl }}$ and perovskite on the spectra Nyquist plots (imaginary versus real part plots). We can note that, for all these high-efficiency cells, no inductive loop at intermediate frequencies was observed. It confirms our previous observation ${ }^{18}$ that this loop is an electric response due to parasitic reactions and is therefore the signature of not optimized devices. ${ }^{18}$ They have been analyzed by using equivalent electrical circuits (EEC). The most general one, established in our previous work ${ }^{42}$ takes into account the possible presence of an inductive loop ${ }^{58}$ and is presented in Figure 7a. In the present work, we have kept the same notations. For each potential, the electrical elements have been extracted by fitting the spectra. For CsFAMA and FAMA, two circle arcs were observed on the spectra (Figure $6 \mathbf{b}$ and Figure 6c). They have been analyzed by using the type III EEC presented in Figure $\mathbf{7 b}$ which contains three resistances and two constant phase elements $(\mathrm{CPE}) . \mathrm{R}_{\mathrm{s}}$ is the series resistance due to the contacts and external wires electrical contributions. It is determined by extrapolating the real part of the spectra at high frequencies to the $\mathrm{X}$-axis. Capacitances have been extracted from the CPE elements using the Brug's protocole ${ }^{61}$ as explained in our previous work. ${ }^{18,19,42-44,60}$ and 
detailed in section $\mathrm{D}$ of the Supporting Information. $\mathrm{CPE}_{2}$ and $\mathrm{CPE}_{4}$ have given $\mathrm{C}_{2}$ and $\mathrm{C}_{4}$, respectively. The type IV EEC shown in Figure 7c was employed for fitting the MAPI spectra (Figure 6a). For these cells, a shoulder was found at intermediate frequencies for most of the $\mathrm{V}_{\text {appl }}$ which led us to employ an EEC with three relaxations, a $\mathrm{R}_{3} / / \mathrm{CPE}_{3}$ element being added.

(a)

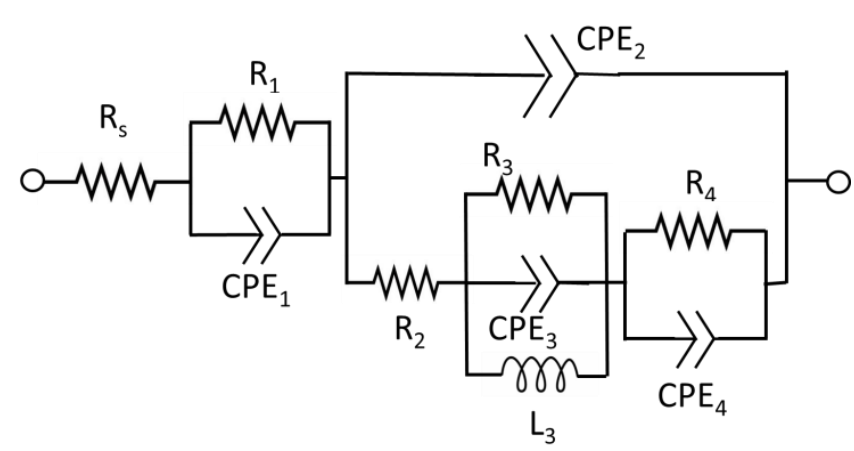

(b)

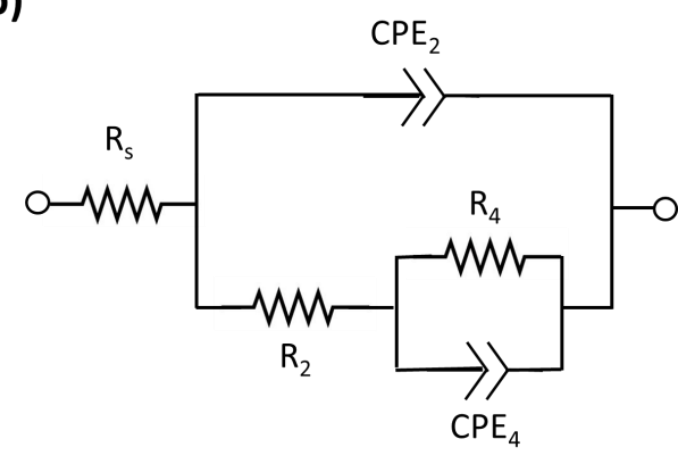

Type III (c)

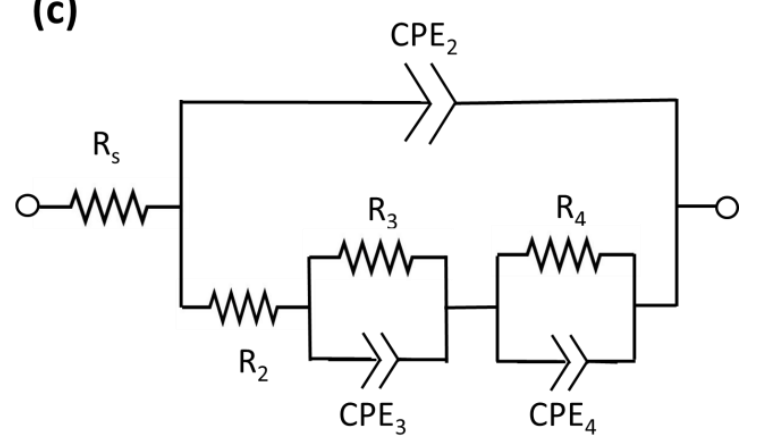

Type IV

Figure 7. (a) General equivalent electrical circuit. (b,c) EECs employed for fitting (b) the FAMA and CsFAMA spectra and (c) the MAPI spectra.

The $\mathrm{C}_{2}$ element is a light insensitive parameter ${ }^{19}$ which values were well-reproducible for each perovskite. Figure 8 displays the variation of $C_{2}$ with the applied voltage $\left(V_{a p p l}\right)$ for the three investigated perovskites. $\mathrm{C}_{2}$ was almost constant below $0.6 \mathrm{~V}$ while, above this value, it increased and formed a $\mathrm{S}$-shaped curve. In the case of FAMA cells, a fast $\mathrm{C}_{2}$ increase was observed at large $\mathrm{V}_{\text {appl. }}$. Below $0.6 \mathrm{~V}, \mathrm{C}_{2}$ is assigned to the bulk dielectric relaxation of the perovskite material. It is related to the relative permittivity of the perovskite, $\varepsilon_{\mathrm{r}}$, according to:

$$
C_{2}=\varepsilon_{r} \varepsilon_{\rho} \rho / d
$$

with $d$ the perovskite layer thickness, $\rho$ the layer roughness factor and $\varepsilon_{0}$ the vacuum permittivity $\left(8.85 \times 10^{-12} \mathrm{~F} \cdot \mathrm{m}^{-1}\right)$. The $\mathrm{C}_{2}$ average values for MAPI is $1.610^{-7} \mathrm{~F}^{-\mathrm{cm}^{-2}}$ with $d$ 
measured on SEM cross-sectional views at circa $370 \mathrm{~nm}$ (Figure 2a). Assuming $\rho=1, \varepsilon_{r}$ is calculated at $\sim 66$ for MAPI. This value is in good agreement with our previous study on a MAPI layer prepared using another protocole. ${ }^{19}$ The same calculation gives $\varepsilon_{r} \sim 41\left(\mathrm{C}_{2} \sim 0.7710^{-7} \mathrm{~F} \mathrm{~cm}^{-}\right.$ $\left.{ }^{2}\right)$ for CsFAMA and $\varepsilon_{r} \sim 41\left(\mathrm{C}_{2} \sim 0.8910^{-7} \mathrm{~F}_{\mathrm{cm}}{ }^{-2}\right)$ for MAPI. These values must be taken with care and are overestimated since they neglect any roughness of the layer.

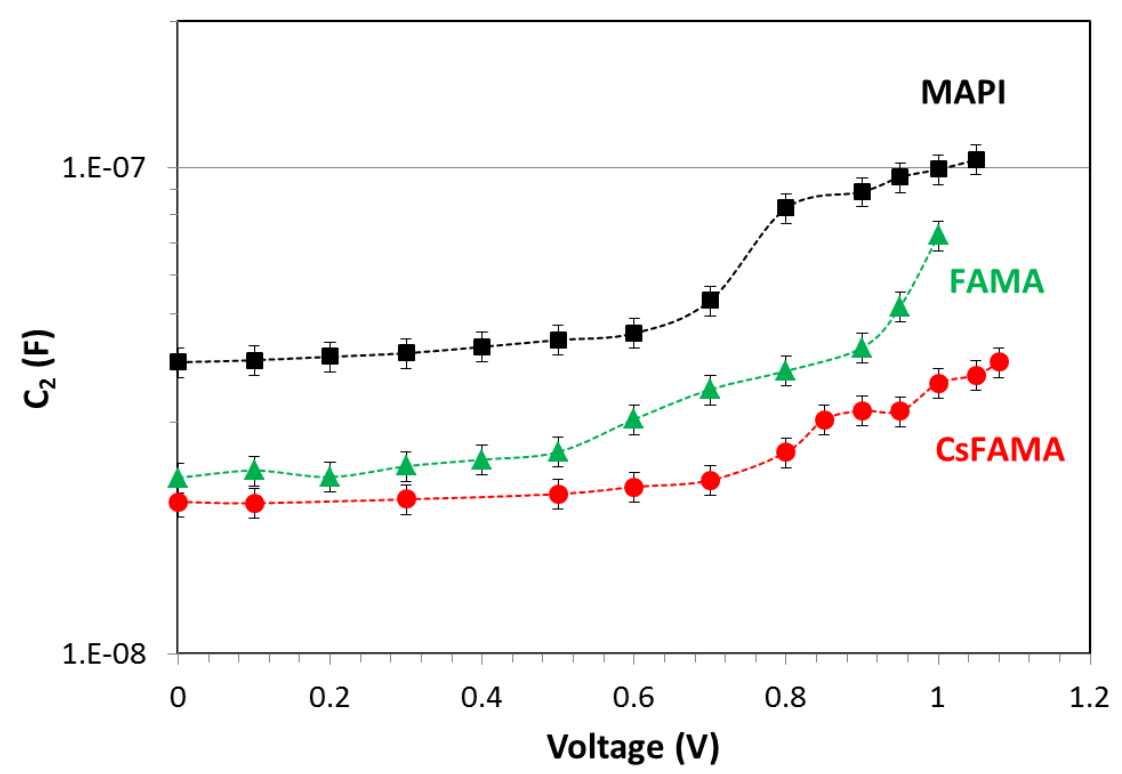

Figure 8. $C_{2}$ parameter versus the applied voltage. Comparison of the three perovskites.

$\mathrm{R}_{2}, \mathrm{R}_{4}$ and $\mathrm{C}_{4}$ elements are light sensitive and are related to the charges photogenerated in the devices. ${ }^{19} \mathrm{R}_{2}$ versus $\mathrm{V}_{\text {appl }}$ curves for the various perovskites are shown in Figure 9a. For $\mathrm{V}_{\text {appl }}<0.9 \mathrm{~V}$, this parameter varies in a large extent with the perovskite. It increases in the order MAPI, CsFAMA and FAMA cells. Above $0.9 \mathrm{~V}$, this parameter drops quickly for the FAMA cell and crosses the other cells curves. This behavior can be linked to the lower $V_{o c}$ measured for these devices and identify $\mathrm{R}_{2}$ as a recombination resistance. At this point it is interesting to analyze more precisely the TRPL curves presented in Figure 4c. They have been fitted by a triexponentials function (Section B, Supporting Information) and the slow decay time (noted $\tau_{\text {slow }}$ ) is found to vary with the perovskite. $\tau_{\text {slow }}$ is measured at $59 \mathrm{~ns}, 93 \mathrm{~ns}$ and $117 \mathrm{~ns}$ for MAPI, CsFAMA and FAMA, respectively (Table S2, Supporting Information). $\tau_{\text {slow }}$ is classically assigned to bulk recombinations (either radiative ${ }^{62,63}$ or non-radiative ${ }^{63,64}$ ) of the photogenerated charges in the perovskite. It scales with the crystal quality and it mitigates with the density of recombination sites in the bulk and at the grain boundaries. We find in Figure 9b an exponential relationship between $\mathrm{R}_{2}$ and $\tau_{\text {slow }}$. 


$$
\mathrm{R}_{2}=1 / \mathrm{k}_{2}=\mathrm{A} \exp \left(\tau_{\text {slow }}\right)
$$

$\mathrm{A}$ is a constant and the fit is excellent $\left(\mathrm{R}^{2}=0.999\right)$. This relationship between $\mathrm{R}_{2}$ and $\tau_{\text {slow }}$ has been assessed by completing the series with a FAMA cell that did not undergo the PEAI treatment (FAMA* dot in Figure 9b). It allows us to assign the $\mathrm{R}_{2}$ component to the recombination occurring in the perovskite layer, especially at the grain boundaries. Recombination resistance $\mathrm{R}_{2}$ is inversely related to the recombination rate $\left(\mathrm{k}_{2}\right)$ and it provides a direct quantitative view of the recombination rate. The higher is this resistance, the lower is the recombination rate.
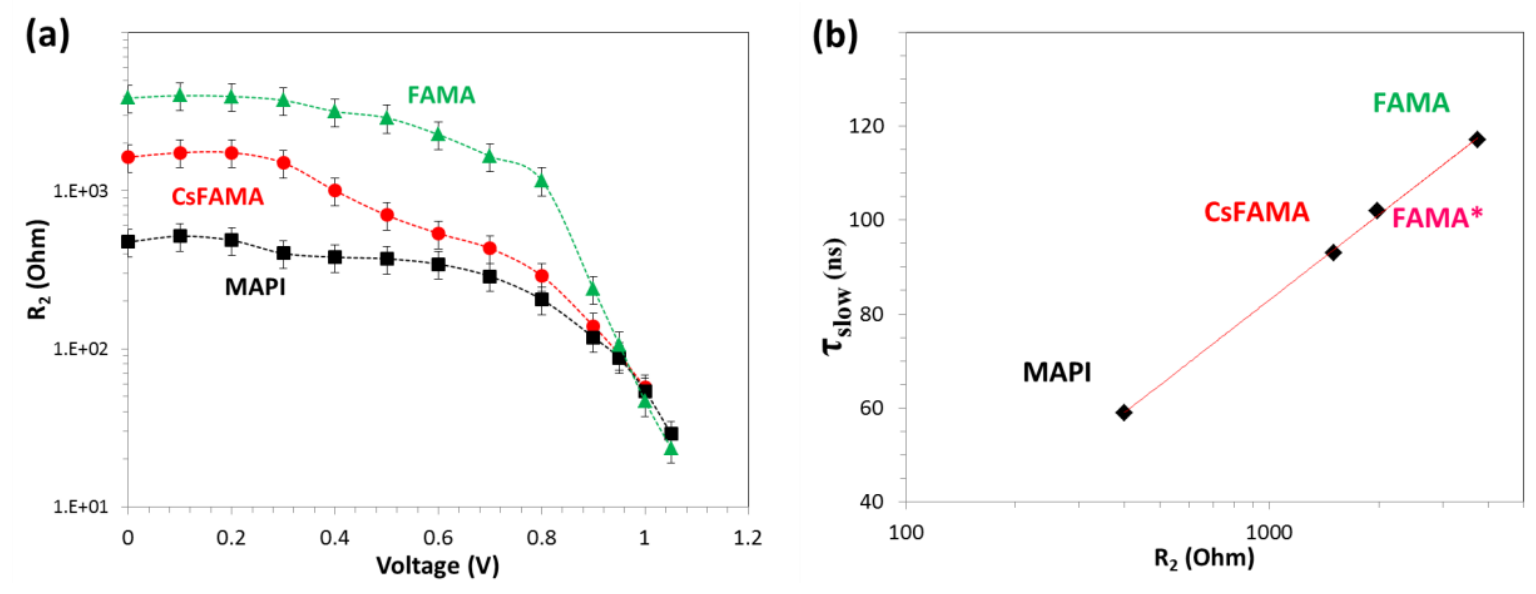

Figure 9. (a) $\mathrm{R}_{2}$ parameters as a function of $\mathrm{V}_{\text {appl }}$ for the three perovskites. (b) $\mathrm{R}_{2}$ (measured at $0.3 \mathrm{~V}$ ) versus $\tau_{\text {slow }}$ of TRPL (FAMA* is a FAMA cell without PEAI treatment). Data recorded under illumination.

$\mathrm{R}_{4}$ is also a recombination resistance but originates from recombinations occurring at or near the interfaces hereafter called interfacial recombinations. In Figure 10a, for $\mathrm{V}_{\text {appl }}<0.8 \mathrm{~V}$, MAPI and CsFAMA have about the same $\mathrm{R}_{4}$ value while FAMA has the highest $\mathrm{R}_{4}$. This cell presents the best interfaces. Above $0.9 \mathrm{~V}, \mathrm{R}_{4}$ of CsFAMA is shifted to higher potential compared to MAPI and FAMA. This is in agreement with the higher $\mathrm{V}_{\text {oc }}$ for CsFAMA cells. The fact of shifting $\mathrm{R}_{2}$ and $\mathrm{R}_{4}$ curves toward higher voltage is favorable for the cell performances since it increases the cell $\mathrm{V}_{\mathrm{OC}}$.

In Table S3 (Supporting Information) we report typical values of $\mathrm{R}_{2}$ and $\mathrm{R}_{4}$ at the $\mathrm{V}_{\text {oc }}$ for the three kinds of cells. The $\mathrm{R}_{2} / \mathrm{R}_{4}$ ratio quantifies the relative interfacial versus bulk recombination rates $\left(\mathrm{k}_{4} / \mathrm{k}_{2}\right)$. We observed that in all cases the interfacial recombination rate is dominant. It increases in the order FAMA (3.0), CsFAMA (4.3) and MAPI (7.3). Extracting the resistance values at the $\mathrm{V}_{\mathrm{oc}}$, therefore, provides a finer view of the recombination 
phenomena than steady-state $\mathrm{V}_{\mathrm{oc}}$ measurements. We have measured $\mathrm{R}_{2}$ at various light intensities and reported their value as a function of the $\mathrm{V}_{\mathrm{oc}}$. An exponential fit was found and an ideality factor, noted $n$ ', has been then determined..$^{40,59}$ The ideality factors obtained from EIS and open-circuit potential measurements ( $n_{\mathrm{ID}}$, see section 3.2) are disclosed in Table $\mathbf{S 4}$ (Supporting Information). Similar values are found from both techniques and they change in a similar manner with the perovskite employed. It confirms $\mathrm{R}_{2}$ as a bulk recombination resistance.
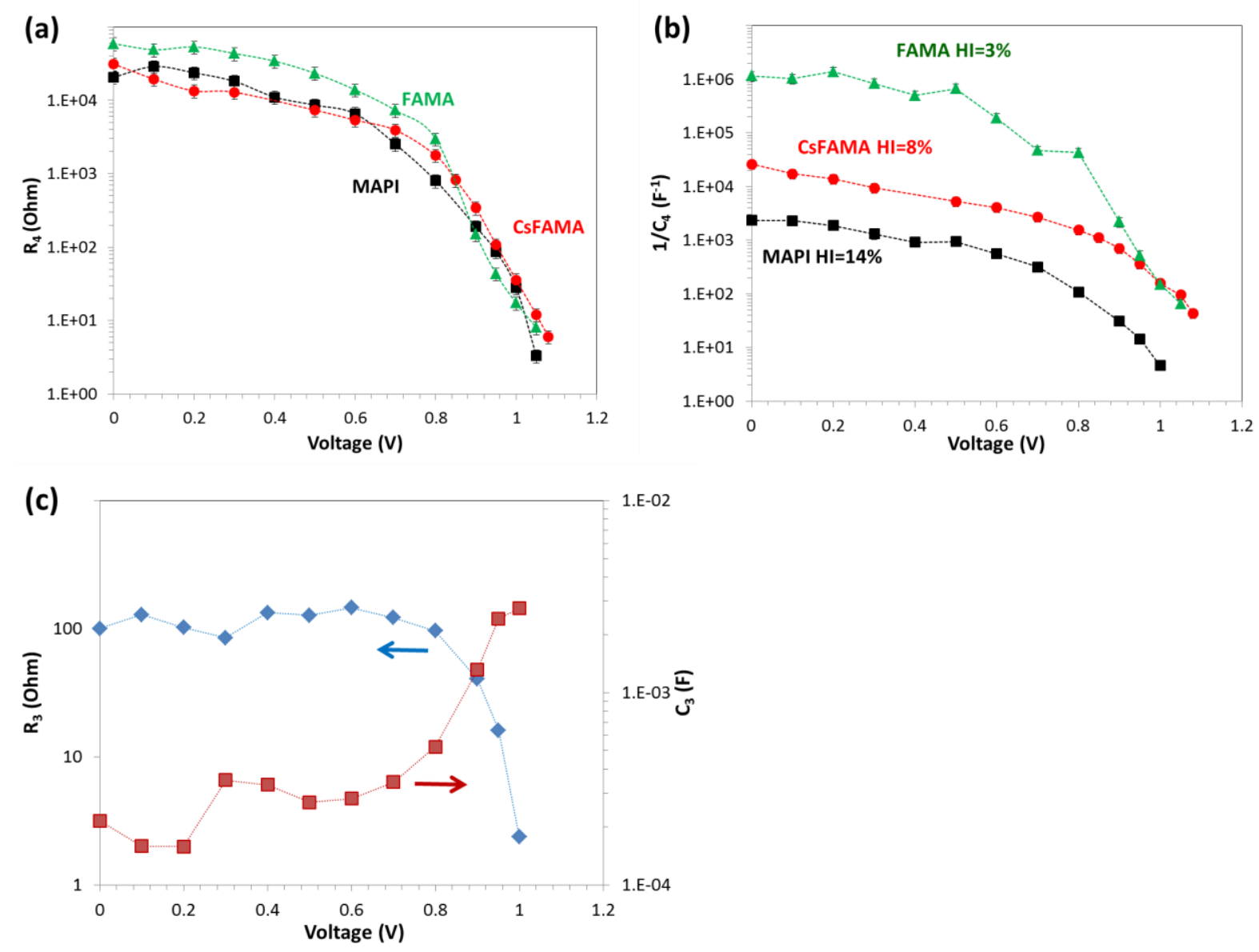

Figure 10. (a) $R_{4}$ and (b) $1 / C_{4}$ parameters versus $V_{\text {appl }}$ for the three perovskites. (c) Variation of $R_{3}$ and $\mathrm{C}_{3}$ of MAPI cells with $\mathrm{V}_{\text {appl }}$.

$\mathrm{C}_{4}$ is a light-sensitive parameter which value dramatically increases with the light irradiation and can reach very high values. ${ }^{19}$ In our case, $\mathrm{C}_{4}$ attained more than $1.10^{-1}{\mathrm{~F} . \mathrm{cm}^{-2}}^{2}$ at high $V_{\text {appl }}$. Jacobs et al. ${ }^{41}$ have shown that such high values cannot be explained by a charge accumulation layer and cannot be the result of photogenerated charges separated across an interface. There is little doubt that $\mathrm{C}_{4}$ is related to the recombination of charges. Because charge recombination in PSC is a phase delayed phenomenon, in addition to the real component, an imaginary component is also introduced. This imaginary component is analyzed in our work as a capacitance in the equivalent electrical circuits used to fit our data (Figure 7). It is the main 


\section{Zheng, T. Zhu, Th. Pauporté ACS Appl. Energy Mater. (2020) DOI/10.1021/acsaem.0c00884}

contribution of $\mathrm{C}_{4}$. This delayed recombination process is a special behavior occurring in PSCs due to the ionic conductivity of the perovskite. The movements of ions introduce defects that act as recombination centers and affect the dynamics of the charges. To better follow the effect of $V_{a p p l}$ and perovskite material, we have chosen to plot the $1 / \mathrm{C}_{4}$ parameter in Figure 10b. This parameter can be directly compared with the recombination resistances. As expected, it dramatically increases from MAPI to CsFAMA and FAMA. Recombinations are suppressed in the latter device. We can also remark that the plot of $1 / C_{4}$ is similar to that of $R_{2}$ (Figure 9a).

The low-frequency capacitance $\mathrm{C}_{4}$ modulates the electrical response of the cells under voltage scan at rather low rate in the $J-V$ curve. It produces a current which depends on the scan direction, rate and the value of $\mathrm{C}_{4}$. The higher $\mathrm{C}_{4}$, the higher the current difference between the forward and reverse scans. A consequence is that $\mathrm{C}_{4}$ is related to the $J-V$ curve hysteresis. It increases from FAMA, CsFAMA and MAPI which exhibit $\mathrm{HI}$ at $\sim 3 \%, \sim 8 \%$ and $\sim 14 \%$, respectively (see Figure 10b). We confirm here that $\mathrm{C}_{4}$ is closely related to the hysteresis index: the higher is $\mathrm{C}_{4}$, the higher is the hysteresis amplitude. ${ }^{19,42}$

In the case of the MAPI cells, we have introduced an intermediate frequency relaxation to well-fit the spectra. The variations of the $\mathrm{R}_{3}$ and $\mathrm{C}_{3}$ parameters with $V_{\text {appl }}$ are presented in Figure 10c. They were batch dependent but we reproducibly observed rather flat curves for $\mathrm{R}_{3}$ and $\mathrm{C}_{3}$ between $0.0 \mathrm{~V}$ and $0.6 \mathrm{~V}$. It reminds the behavior of $\mathrm{C}_{2}$ and may be related to bulk properties rather than interfacial ones. However, with the actual knowledge on the EIS response of PSCs, it is difficult to clearly state which physical process occurring in the cells is at the origin of these parameters.

The conclusion of the EIS investigation is that for PSC of very high efficiency, $R_{s}$ must be minimized; $R_{2}, R_{4}$ and $1 / C_{4}$ must be the highest as possible to get high $\mathrm{J}_{\mathrm{sc}}$ and FF. Moreover, for a high FF, the drop of these light-sensitive components must be as abrupt as possible and for a high $\mathrm{V}_{\mathrm{oc}}$, the drop must be voltage-shifted at most.

\subsection{Electrical stability of the devices}

The future of the perovskite technology will depend on the ability of obtaining stable devices. Their robustness against electrical stresses and light irradiation are key parameters that must be carefully investigated. We performed a first test consisting in measuring the $J$ - $V$ curves of the cells, before and after their EIS investigation. ${ }^{11}$ EIS measurements, in which PSCs are 
submitted to a continuous light irradiation, to the application of many voltages and to a superimposed ac stimulus during about one hour, are especially stressing for the PSCs. Table 2 reports the $J-V$ curves result before and after the EIS characterization, for the different perovskites. The performances of the MAPI cells measured on the reverse scan slightly increased upon the measurements. The PCE of the forward scan was decreased due to the FF parameter mitigation. The CsFAMA cells were the most affected by the EIS measurements. Their efficiency was measured lower after the EIS characterization. FAMA devices were remarkably stable since they exhibited a slightly higher PCE after EIS characterizations due to the increase of the $V_{O C}$. Their HI parameter remained low and almost unchanged.

Table 2. $J$ - $V$ curves parameters of PSCs with various perovskites before and after their investigation by EIS.

\begin{tabular}{|c|c|c|c|c|c|c|c|}
\hline Sample & & & $\mathbf{V}_{\text {oc }} / \mathbf{V}$ & $\begin{array}{l}J_{\text {sc }} \\
\text { mA.cm }\end{array}$ & FF / \% & PCE / \% & $\mathrm{HI} / \%$ \\
\hline \multirow{4}{*}{ MAPI } & \multirow{2}{*}{ Before } & Reverse & 1.045 & 22.19 & 78.42 & 18.18 & \multirow{2}{*}{12} \\
\hline & & Forward & 1.026 & 22.18 & 70.19 & 15.97 & \\
\hline & \multirow{2}{*}{ After } & Reverse & 1.057 & 23.19 & 75.87 & 18.60 & \multirow{2}{*}{16} \\
\hline & & Forward & 1.033 & 23.13 & 65.41 & 15.63 & \\
\hline \multirow{4}{*}{ CsFAMA } & \multirow{2}{*}{ Before } & Reverse & 1.077 & 21.81 & 77.63 & 18.24 & \multirow{2}{*}{7} \\
\hline & & Forward & 1.052 & 21.81 & 73.63 & 16.88 & \\
\hline & \multirow{2}{*}{ After } & Reverse & 1.049 & 21.64 & 74.18 & 16.83 & \multirow{2}{*}{8} \\
\hline & & Forward & 1.027 & 21.66 & 69.23 & 15.40 & \\
\hline \multirow{4}{*}{ FAMA } & \multirow{2}{*}{ Before } & Reverse & 1.035 & 25.65 & 79.62 & 21.13 & \multirow{2}{*}{2} \\
\hline & & Forward & 1.031 & 25.69 & 77.81 & 20.61 & \\
\hline & \multirow{2}{*}{ After } & Reverse & 1.044 & 25.71 & 79.36 & 21.29 & \multirow{2}{*}{3} \\
\hline & & Forward & 1.045 & 25.71 & 77.17 & 20.73 & \\
\hline
\end{tabular}

We also compared the stability of the unencapsulated solar cells under a one sun AM 1.5G light irradiation and at a relative humidity $(\mathrm{RH})$ of $45 \%$, tracking them at their maximum power points (MPP). The curves are disclosed in Figure 11a. During $200 \mathrm{~min}$, the MAPI cell presented the fastest decrease. The fact that the MAPI cell was less stable under the solar simulator compared to the EIS measurement could be due to the UV light component in the former irradiation spectrum. The CsFAMA cell PCE decreased more slowly at the beginning but the two curves crossed at $200 \mathrm{~min}$. After $300 \mathrm{~min}$, the MAPI cell had lost 37\% of its initial PCE and the CsFAMA cell $42 \%$. The FAMA cell was remarkably stable and no PCE loss was 
observed. Figures 11b-d are the $J$ - $V$ curves measured before and after the tracking experiments. MAPI cell presented a lower $\mathrm{V}_{\mathrm{oc}}$ and a large hysteresis after the stability test. CsFAMA cell exhibited a decrease of the $\mathbf{J}_{\mathrm{sc}}$ and an enlargement of the hysteresis. We noted a remarkable stability of the FAMA cell under the test since the $J$ - $V$ curves were unchanged after the long irradiation and tracking period.
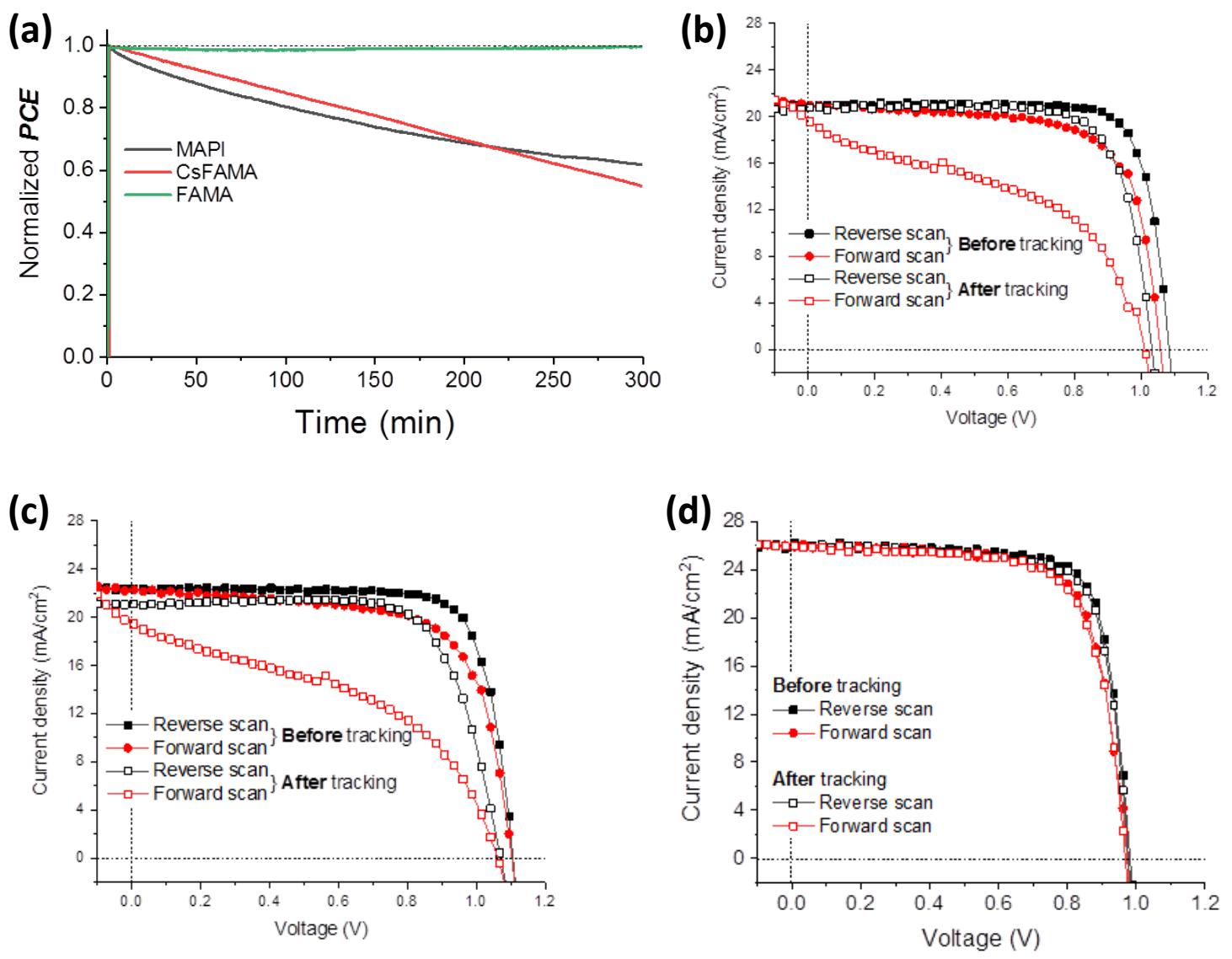

Figure 11. (a) Tracking of MAPI, CsFAMA and FAMA solar cells normalized power outputs under continuous one sun AM1.5G illumination (unencapsulated devices $45 \% \mathrm{RH}$ ). (b-d) $J$ - $V$ curves were measured before and after the tracking experiment under 1sun AM1.5G illumination. (b) MAPI; (c) CsFAMA and (d) FAMA cells.

This paper focusses on the effect of the monovalent cation composition on the electrical properties of PSCs. A study of the PSCs stability under high-moisture environment is given in Section E of the Supporting Information. None of them, when unencapsulated, were highly robust when stored in a chamber with a $90 \% \mathrm{RH}$ at $20^{\circ} \mathrm{C}$ (Figure $\mathbf{S 4}$ and Figure S6, Supporting Information). It can be assigned to the presence of the hydrophilic MA cation in their structure. They should need additional efficient barrier layers against moisture to be fully stabilized. The 
final PCE was the best for FAMA. We have also found that MAPI was decomposed upon aging in $\mathrm{PbI}_{2}$ with the elimination of MAI (MAI can be degraded into volatile $\mathrm{CH}_{3} \mathrm{I}$ and $\mathrm{NH}_{3}$ molecules). ${ }^{26}$ On the other hand, CsFAMA and FAMA were degraded in the photo-inactive one-dimensional (1D) $\delta$-phase that may be regenerated in their photoactive $\alpha$-phase, for instance by heating (Figure S5, Supporting Information).

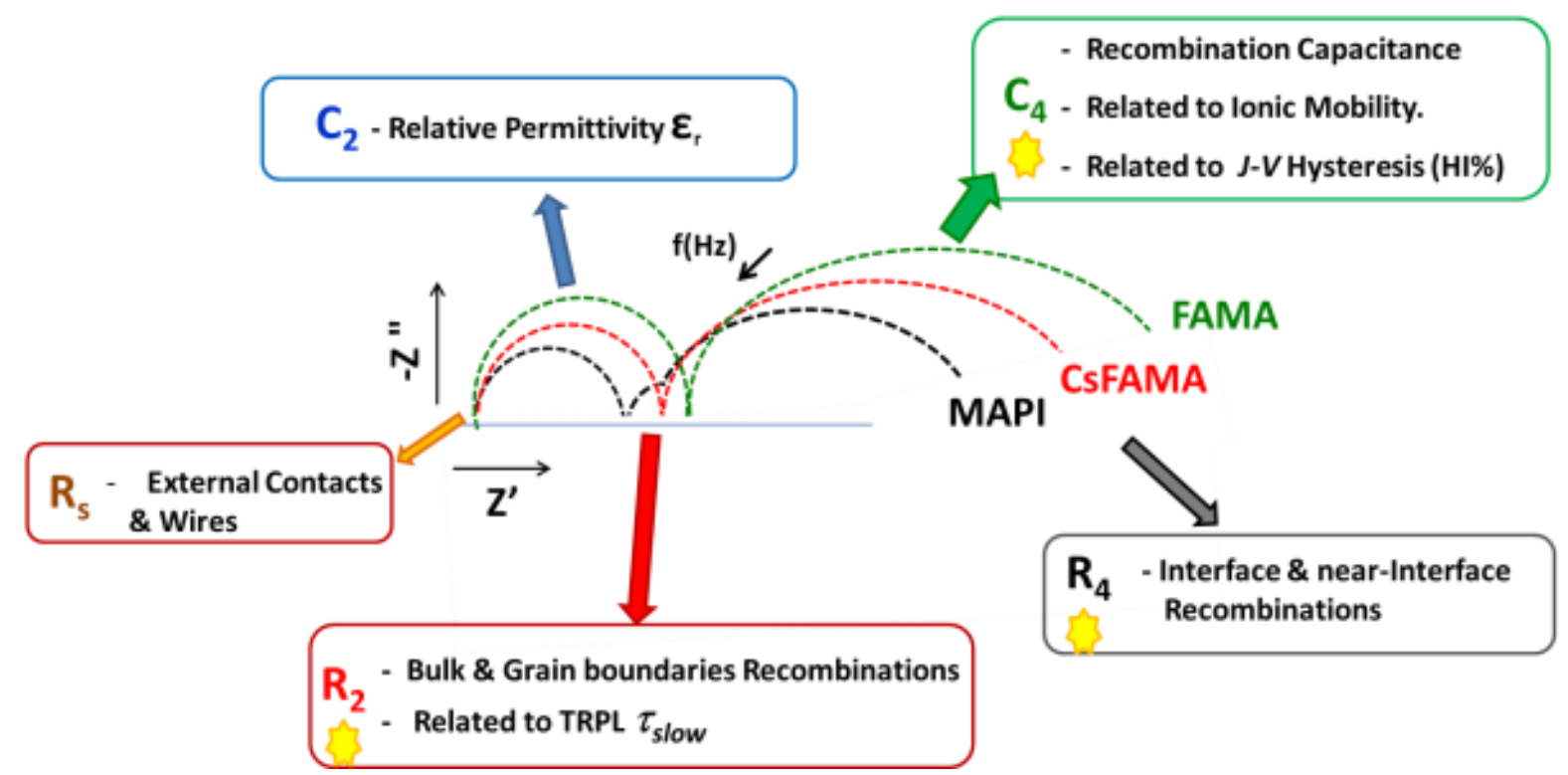

Scheme1. Main information extracted from the electrical impedance spectroscopy data and their correlations with other measurements. Light sensitive element.

\section{Conclusions}

In conclusion, we have fully investigated the electrical response of solar cells prepared with perovskite ranging from the mono-cation to the tri-cation composition. The best results have been found with the double MA/FA lead iodide compound which was prepared using MACl additive in the precursor solution. This strategy has been found the most accurate to achieve high efficiency and stability. It is more efficient than to complicate the perovskite composition. FAMA presented the best morphology, crystallinity and optical properties for the application. The ideality factor decreased from MAPI, CsFAMA and FAMA. For the later SRH recombination with the less intensity was found. The cells have been thoroughly investigated by impedance spectroscopy over a wide applied potential range. We have proposed two EECs based on our general EEC for analyzing the electrical response of the three kinds of solar cells. For all these optimized devices, with high efficiency for their category, no inductive loop at intermediate-frequency due to parasitic reaction was found. The main information extracted 
from the electrical impedance spectroscopy data and their correlations with other measurements are summarized in Scheme 1. We have extracted the dielectric permittivity of the three perovskites from the high-frequency capacitance $C_{2}$ and measured them at 66,41 and 41 for MAPI, CsFAMA and FAMA, respectively. We have found a fair relationship between the highfrequency resistance $\mathrm{R}_{2}$ and the slow decay time $\tau_{\text {slow }}$ of the OIHP TRPL. This has led us to assign $\mathrm{R}_{2}$ to recombination occurring in the perovskite bulk and grain boundaries. The lowfrequency resistance $\mathrm{R}_{4}$ has been assigned to the recombination at and near the interfaces. The low-frequency capacitance $\mathrm{C}_{4}$ which modulates the electrical response of the cells under voltage scan at rather low rate has been assigned to a phase delayed recombination phenomenon, the delay being a consequence of the ionic mobility and defect formation. For these three recombination related electrical elements, the best values have been found for our highly efficient FAMA cell which is almost hysteresis-free. Finally, under electrical and light irradiation stresses, the investigated FAMA cell was highly stable while MAPI was more stable than CsFAMA. Finally, the strategy of mediating the growth of $\mathrm{FA}_{1-\mathrm{x}} \mathrm{MA}_{\mathrm{x}} \mathrm{PbI}_{3}$ perovskite double cation by $\mathrm{MACl}$ additive is found the best to suppress recombinations, suppress ion mobility, reach high efficiency with low hysteresis and stabilize the perovskite compound.

\section{Acknowledgements}

Mr J. Liu and Dr L. Coolen (INSP, Sorbonne University, France) are acknowledged for TRPL measurements. T.Z. thanks the Chinese Scholarship Council and D.Z thanks the Chinese Scholarship Council-Paristech programme for Ph.D scholarships (grant numbers 201706340053 and 201806310126, respectively). The ANR agency is acknowledged for financial support (Moreless project ANR-18-CE05-0026).

\section{Supporting Information}

The Supporting Information is available free of charge at https://pubs.acs.org/doi/ XXXXXXXXXXXXXXXXXXXXXXXXXX

Complementary experimental details; XRD patterns of the perovskite layers; EDX analysis; Optical characterizations of the three perovskite layers; Fitting of the TRPL curves; TRPL curves parameters; J-V forward and reverse curves of the three perovskites solar cells; Analysis of the impedance spectra; $\mathrm{R}_{2}$ and $\mathrm{R}_{4}$ measured at the $\mathrm{V}_{\mathrm{oc}}$; Comparison of the ideality factors determined from EIS and $V_{o c}$ measurements; Aging tests at high moisture. 


\section{References}

(1) Kim, H.S.; Lee, C.R.; Im, J.H.; Lee, K.H.; Moehl, T.; Marchioro, A.; Moon, S.J.; Robin, H.B.; Yum, J.H.; Moser, J.E.; Gratzel, M. Lead Iodide Perovskite Sensitized All-Solid-State Submicron Thin Film Mesoscopic Solar Cell with Efficiency Exceeding 9\%. Sci. Rep. 2012, 2, 591.

(2) Leyden, M.R.; Terakawa, S.; Matsushima, T.; Terakawa, S.; Ruan, S.; Goushi, K.; Auffray, M; Sandanayaka, A.S.D.; Qin, C.Y.; Bencheikh, F.; Adachi, C. Distributed Feedback Lasers and Light-Emitting Diodes Using 1-Naphthylmethylamnonium Low-Dimensional Perovskite. ACS Photonics 2019, 6, 460-466.

(3) Wei, Y.; Cheng, Z.Y.; Lin, J. An Overview on Enhancing the Stability of Lead Halide Perovskite Quantum Dots and Their Applications in Phosphor-Converted LEDs. Chem. Soc. Rev. 2019, 48, 310-350.

(4) Miao, J.L.; Zhang, F.J. Recent Progress on Highly Sensitive Perovskite Photodetectors. J. Mater. Chem. C 2019, 7, 1741-1791.

(5) Mykhaylyk, V.B.; Kraus, H.; Saliba, M. Bright and Fast Scintillation of Organolead Perovskite $\mathrm{MAPbBr}_{3}$ at Low Temperatures. Mater. Horiz. 2019, 6, 1740-1747.

(6) Zhu, T.; Zheng, D.; Rager, M.-N.; Pauporté, T. Actual Organic Cations Composition Determination in Perovskite Thin Films. Application to Formamidinium Lead Iodide Stabilization for High Efficiency Solar Cell. Sol. RRL 2020, 2000348.

(7) Zhang, J.; Barboux, P.; Pauporté, Th. Electrochemical Design of Nanostructured ZnO Charge Carrier Layers for Efficient Solid-State Perovskite-Sensitized Solar Cells. Adv. Energy Mater. 2014, 4, 1400932.

(8) Zhang, J.; Juárez-Pérez, E.J.; Mora-Seró, I.; Viana, B.; Pauporté, Th. Fast and Low Temperature Growth of Electron Transport Layers for Efficient Perovskite Solar Cells. $J$. Mater. Chem. A. 2015, 3, 4909-4915.

(9) Yoo, J.J.; Wieghold, S.; Sponseller, M.C.; Chua, M.R.; Bertram, S.N.; Hartono, N.T.P.; Tresback, J.S.; Hansen, E.C.; Correa, B.J.P.; Bulovic, V.; Buonassisi, T.; Shin, S.S.; Bawendi, M.G. An Interface Stabilized Perovskite Solar Cell with High Stabilized Efficiency and Low Voltage Loss. Energy Environ. Sci. 2019, 12, 2192-2199.

(10) Liu, Y.; Akin, S.; Pan, L.; Uchida, R.; Arora, N.; Milic, J.V.; Hinderhofer, A.; Schreiber, F.; Uhl, A.R.; Zakeeruddin, S.M.; Hagfeldt, A.; Dar, M.L.; Gratzel, M. Ultrahydrophobic 3D/2D Fluoroarene Bilayer-Based Water-Resistant Perovskite Solar Cells with Efficiencies Exceeding 22\%. Sci. Adv. 2019, 5, eaaw2543.

(11) Pitarch-Tena, D.; Ngo, T.T.; Vallés-Pelarda, M.; Pauporté, Th.; Mora-Seró, I. Impedance Spectroscopy Measurements in Perovskite Solar Cells. Device Stability During the Measurement and Noise Reduction. ACS Energy Lett. 2018, 3, 1044-1048. 
(12) Nie, W.; Tsai, H.; Asadpour, R.; Blancon, J. C.; Neukirch, A. J.; Gupta, G.; Crochet, J. J.; Chhowalla, M.; Tretiak, S.; Alam, M. A.; Wang, H. L. Solar cells. High-Efficiency SolutionProcessed Perovskite Solar Cells with Millimeter-Scale Grains. Science 2015, 347, 522-525.

(13) Zhang, J.; Pauporté, T. Effects of Oxide Contact Layer on the Preparation and Properties of $\mathrm{CH}_{3} \mathrm{NH}_{3} \mathrm{PbI}_{3}$ for Perovskite Solar Cell Application. J. Phys. Chem. C 2015, 119, 14919-14928.

(14) Zhang, J.; Pauporté, T. One-Dimensional Self-Standing $\mathrm{TiO}_{2}$ Nanotube Array Layers Designed for Perovskite Solar Cell Applications. ChemPhysChem, 2015, 16, 2836-2841.

(15) Tu, Y. G.; Xu, G. N.; Yang, X. Y.; Zhang, Y. F.; Li, Z. J.; Su, R.; Luo, D. Y.; Yang, W. Q.; Miao, Y.; Cai, R.; Jiang, L. H.; Du, X. W.; Yang, Y. C.; Q. Liu, S.; Gao, Y.; Zhao, S.; Huang, W.; Gong, Q. H.; Zhu, R. Mixed-Cation Perovskite Solar Cells in Space. Sci. ChinaPhys. Mech. Astron. 2019, 62, 974221-1-974221-4.

(16) Yang, W. S.; Park, B. W.; Jung, E. H.; Jeon, N. J.; Kim, Y. C.; Lee, D. U.; Shin, S. S.; Seo, J. E.; Kim, K.; Noh, J. H.; Seok, S. I. Iodide Management in Formamidinium-Lead-HalideBased Perovskite Layers for Eefficient Solar Cells. Science 2017, 356, 1376-1379.

(17) Leblanc, A.; Mercier, N.; Allain, M.; Dittmer, J.; Fernandez, V.; Pauporté, T. Lead- and Iodide-Deficient $\left(\mathrm{CH}_{3} \mathrm{NH}_{3}\right) \mathrm{PbI}_{3}$ (d-MAPI): The Bridge Between $2 \mathrm{D}$ and 3D Hybrid Perovskites. Angew. Chem., Int. Ed. 2017, 56, 16067-16072.

(18) Wang, P.; Shao, Z.; Ulfa, M.; Pauporté, T. Insights into the Hole Blocking Layer Effect on the Perovskite Solar Cell Performance and Impedance Response. J. Phys. Chem. C 2017, 121, 9131-9141.

(19) Wang, P. J.; Ulfa, M.; Pauporté, T. Effects of Perovskite Monovalent Cation Composition on the High and Low Frequency Impedance Response of Efficient Solar Cells. J. Phys. Chem. C 2018, 122, 1973-1981.

(20) Stranks, S.D.; Eperon, G.E.; Grancini, G.; Menelaou, C.; Alcocer, M.J.P.; Leijtens, T.; Herz, L.M., Petrozza, A.; Snaith, H.J. Electron-Hole Diffusion Lengths Exceeding 1 Micrometer in an Organometal Trihalide Perovskite Absorber. Science 2013, 342, 341-344.

(21) Leung, S.F.; Ho, K.T.; Kung, P.K.; Hsiao, V.K.S.; Alshareef, H.N.; Wang, Z.L.; He, J.H. A Self-Powered and Flexible Organometallic Halide Perovskite Photodetector with Very High Detectivity. Adv. Mater. 2018, 30, 1704611.

(22) NREL chart 2020, https://www.nrel.gov/pv/cell-efficiency.html.

(23) Bartel, C. J.; Sutton, C. B.; Goldsmith, R.; Ouyang, R.; Musgrave, C. B.; Ghiringhelli, L.M.; Scheffler., M. New Tolerance Factor to Predict the Stability of Perovskite Oxides and Halides. Sci. Adv. 2019, 5, eaav0693.

(24) M.; Matsui, T.; Seo, J.-Y.; Domanski, K.; Correa-Baena, J.-P.; Nazeeruddin, M. K.; Zakeeruddin, S. M.; Tress, W.; Abate, A.; Hagfeldt, A.; Grätzel, M. Cesium-Containing Triple Cation Perovskite Solar Cells: Improved Stability, Reproducibility and High Efficiency. Energy Environ. Sci. 2016, 9, 1989-1997. 
(25) Saliba, M.; Matsui, T.; Domanski, K.; Seo, J.-Y.; Ummadisingu, A.; Zakeeruddin, S. M.; Correa-Baena, J.-P.; Tress, W.R.; Abate, A.; Hagfeldt, A.; Grätzel, M. Incorporation of Rubidium Cations into Perovskite Solar Cells Improves Photovoltaic Performance. Science 2016, 354, 206-209.

(26) Turren-Cruz, S.-H.; Hagfeldt, A.; Saliba, M. Methylammonium-Free, High-Performance, and Stable Perovskite Solar Cells on a Planar Architecture. Science 2018, 362, 449-453.

(27) Kim, M.; Kim, G.H.; Lee, T.K.; Choi, I.W.; Choi, H.W.; Jo, Y.; Yoon, Y.J.; Kim, J.W.; Lee, J.; Huh, D.; Lee, H.; Kwak, S.K.; Kim, J. Y.; Kim, D. S. Methylammonium Chloride Induces Intermediate Phase Stabilization for Efficient Perovskite Solar Cells. Joule 2019, 3, 114.

(28) Zhu, T.; Su, J.; Labat, F.; Ciofini, I.; Pauporté, Th. Interfacial Engineering through Chloride-Functionalized Self-Assembled Monolayer for High Efficiency Perovskite Solar Cells. ACS Appl. Mater Interfaces 2020, 12, 744-752.

(29) Ulfa, M.; Wang, P.; Shao, Z.; Viana, B.; Pauporté, T. Oxide Hole Blocking Selective Contacts in Perovskite Solar Cells. Proc. SPIE 2018, 10533, 105332R1-105332R10.

(30) Nazeeruddin, M. K.; Braukyla, T.; Xia, R.; Daskeviciene, M.; Malinauskas, T.; Gruodis, A.; Jankauskas, V.; Roldán-Carmona, C.; Momblona, C.; Getautis, V.; Fei, Z. Inexpensive Hole Transporting Materials Derived from Tröger's Base Afford Efficient and Stable Perovskite Solar Cells. Angew. Chem. Int. Ed. 2019, 58, 11266-11272.

(31) Xia, R.; Fei, Z.; Drigo, N.; Bobbink, F. D.; Huang, Z.; Jasiūnas, R.; Franckevičius, M.; Gulbinas, V.; Mensi, M.; Fang, X.; Roldán-Carmona, C. Retarding Thermal Degradation in Hybrid Perovskites by Ionic Liquid Additives. Adv. Funct. Mater. 2019, 29, 1902021.

(32) Le Bahers, T.; Labat, F.; Pauporté, T.; Ciofini, I. Effect of Solvent and Additives on the Open Circuit Voltage of ZnO Based Dye-Sensitized Solar Cells: A Combined Theoretical and Experimental Study. Phys. Chem. Chem. Phys. 2010, 12, 14710-14719.

(33) Kusumawati, Y.; Martoprawiro, M. A.; Pauporté, Th. Effects of Graphene in Graphene/ $\mathrm{TiO}_{2}$ Composite Films Applied to Solar Cell Photoelectrode. J. Phys. Chem. C 2014, 118, 9974-9981.

(33) Zong, B.; Fu, W.; Guo, Z.A.; Wang, S.; Huang, L.; Zhang, B.; Bala, H.; Cao, J.; Wang, X.; Sun, G.; Zhang, Z. Highly Stable Hole-Conductor-Free Perovskite Solar Cells Based Upon Ammonium Chloride and a Carbon Electrode. J. Colloid Interface Sci. 2019, 540, 315-321.

(34) Rong, Y.; Hou, X.; Hu, Y.; Mei, A.; Liu, L.; Wang, P.; Han, H. Synergy of Ammonium Chloride and Moisture on Perovskite Crystallization for Efficient Printable Mesoscopic Solar Cells. Nat. Commun, 2017, 8, 14555.

(35) Dai, X.Z.; Deng, Y.H.; Charles, H.; Brackle, V.; Chen, S.S.; Rudd, P.N.; Xiao, X.; Lin, Y.; Chen, B.; Huang, J.S. Scalable Fabrication of Efficient Perovskite Solar Modules on Flexible Glass Substrates. Adv. Energy Mater. 2020, 10, 1903108. 
(36) Aldibaja, F.K.; Badia, L.; Mas-Marza, E.; Sanchez, R.S.; Barea, E.M.; Mora-Sero, I. Effect of Different Lead Precursors on Perovskite Solar Cell Performance and Stability. J. Mater. Chem. A 2015, 3, 9194-9200.

(37) Xie, F.; Chen, C.-C. ; Wu, Y.; Li, X. ; Cai, M. ; Liu, X. ; Yang, X. ; Han, L. Vertical Recrystallization for Highly Efficient and Stable Formamidinium-Based Inverted-Structure Perovskite Solar Cells, Energy Envinron. Sci. 2017, 10, 1942-1949.

(38) Yoo, H.-S, Park, N.G. Post-Treatment of Perovskite Film with Phenylalkylammonium Iodide for Hysteresis-Less Perovskite Solar Cells. Sol. Energy Mater. Sol. Cells 2018, 179, 5765

(39) Tress, W.; Yvari, M.; Domanski, K.; Yadav, P.; Niesen, B.; Correa Baena, J.P.; Hagffeldt, A.; Graetzel, M. Interpretation and Evolution of Open-Circuit Voltage, Recombination, Ideality Factor, Subgap Defect States During Reversible Light-Soaking and Irreversible Degradation of Perovskite Solar Cells. Energy Environ. Sci. 2018, 11, 151-165.

(40) Contreras-Bernal, L.; Salado, M.; Todinova, A. ; Calio, L. ; Ahmad, S.; Idigoras, J.; Anta, J.A. Origin and Whereabout of Recombination in Perovskite Solar Cells. J. Phys. Chem. C 2017, 121, 9705-9713.

(41) Jacobs, D. A.; Shen, H.; Pfeffer, F.; Peng, J.; White, T. P.; Beck, F.J.; Catchpole, K.R. The Two Faces of Capacitance: New Interpretations for Electrical Impedance Measurements of Perovskite Solar Cells and their Relation to Hysteresis. J. Appl. Phys. 2018, 124, 225702.

(42) Ulfa, M.; Zhu, T.; Goubard, F.; Pauporté, T. Molecular versus Polymeric Hole Transporting Materials for Perovskite Solar Cell Application. J. Mater. Chem. A 2018, 6, 13350-13358.

(43) Ulfa, M.; Wang, P.J.; Zhang, J.; Liu, W.; Marcillac, D.; Coolen, L.; Peralta, S.; Pauporté, T. Charge Injection and Electrical Response in Low-Temperature $\mathrm{SnO}_{2}$-Based Efficient Perovskite Solar Cells. ACS Appl. Mater. Interfaces 2018, 10, 35118-35128.

(44) Ulfa, M.; Pauporté, T.; Bui, T.T.; Goubard, F. Impact of Organic Hole Transporting Material and Doping on the Electrical Response of Perovskite Solar Cells. J. Phys. Chem. C. 2018, 122, 11651-11658.

(45) Almora, O.; Aranda, C.; Mas-Marzá, E.; Garcia-Belmonte, G. On Mott-Schottky Analysis Interpretation of Capacitance Measurements in Organometal Perovskite Solar Cells. Appl. Phys. Lett. 2016,109, 173903.

(46) Pascoe, A.R; Duffy, N.W.; Scully, A.D.; Huang, F.; Cheng, Y.B. Insights into Planar $\mathrm{CH}_{3} \mathrm{NH}_{3} \mathrm{PbI}_{3}$ Perovskite Solar Cells using Impedance Spectroscopy. J. Phys. Chem. C 2015, $119,4444-4453$

(47) Juarez-Perez, E.J.; Wußler, M.; Fabregat-Santiago, F.; Lakus-Wollny,K.; Mankel, E.; Mayer, T.; Jaegermann, W.; Mora-Sero, I. Role of the Selective Contacts in the Performance of Lead Halide Perovskite Solar Cells. J. Phys. Chem. Lett. 2014, 5, 680-685. 
(48) Juarez-Perez, E.J.; Sanchez, R.S.; Badia, L.; Garcia-Belmonte, G.; Kang, Y.S.; Mora-Sero, I.; Bisquert, J. Photoinduced Giant Dielectric Constant in Lead Halide Perovskite Solar Cells. J. Phys. Chem. Lett. 2014, 5, 2390-2394.

(49) Dualeh, A.; Moehl, T.; Tétreault, N.; Teuscher, J.; Gao, P.; Nazeeruddin, M.K.; Grätzel, M. Impedance Spectroscopic Analysis of Lead Iodide Perovskite-Sensitized Solid-State Solar Cells. Sci. Rep. 2014, 8, 362-373.

(50) Gonzalez-Pedro, V.; Juarez-Perez, E.J.; Arsyad, W.S.; Barea, E.M.; Fabregat-Santiago, F.; Mora-Sero, I.; Bisquert, J. General Working Principles of $\mathrm{CH}_{3} \mathrm{NH}_{3} \mathrm{PbX}_{3}$ Perovskite Solar Cells. Nano Lett. 2014, 14, 888-893.

(51) Almora, O.; Zarazua, I.; Mas-Marza, E.; Mora-Sero, I.; Bisquert, J.; Garcia-Belmonte, G. Capacitive Dark Currents, Hysteresis, and Electrode Polarization in Lead Halide Perovskite Solar Cells. J. Phys. Chem. Lett. 2015, 6, 1645-1652.

(52) Guerrero, A.; Juarez-Perez, E.J.; Bisquert, J.; Mora-Sero, I.; Garcia-Belmonte, G. Electrical Field Profile and Doping in Planar Lead Halide Perovskite Solar Cells. Appl. Phys. Lett. 2014, 105, 133902.

(53) Kim, H.-S.; Mora-Sero, I.; Gonzalez-Pedro, V.; Fabregat-Santiago, F.; Juarez-Perez, E. J.; Park, N.-G.; Bisquert, J. Mechanism of Carrier Accumulation in Perovskite Thin-Absorber Solar Cells. Nat. Commun. 2013, 4, 2242.

(54) Zarazua, I.; Han, G.F.; Boix, P.P.; Mhaisalkar, S.; Fabregat-Santiago, F.; Mora-Sero, I.; Bisquert, J.; Garcia-Belmonte, G. Surface Recombination and Collection Efficiency in Perovskite Solar Cells from Impedance Analysis. J. Phys. Chem. Lett., 2016, 7, 5105-5113.

(55) Yang, T.-Y.; Gregori, G.; Pellet, N.; Grätzel, M.; Maier, J. The Significance of Ion Conduction in a Hybrid Organic-Inorganic Lead Iodide-Based Perovskite Photosensitizer. Angew. Chem., Int. Ed. 2015, 54, 7905-7910.

(56) Anaya M.; Zhang, W.; Clasen Hames, B.; Li, Y.; Fabregat-Santiago, F.. Calvo, M.E.; Snaith, H.J.; Miguez, H.; Mora-Sero I. Electron Injection and Scaffold Effects in Perovskite Solar Cells. J. Mater. Chem. C 2017, 5, 634-644.

(57) Pockett, A.; Eperon, G. E.; Sakai, N.; Snaith, H. J.; Peter, L. M.; Cameron, P. J. Microseconds, Milliseconds and Seconds: Deconvoluting the Dynamic Behavior of Planar Perovskite Solar Cells. Phys. Chem. Chem. Phys. 2017, 19, 5959-5970.

(58) Guerrero, A.; Garcia-Belmonte, G.; Mora-Sero, I. ; Bisquert, J. ; Kang, Y.S. ; Jacobsson, T.J. ; Correa-Baera, J.P. ; Hagfeldt, A. Properties of Contact and Bulk Impedance in Hybrid Lead Halide Perovskite Solar Cells Including Inductive Loop Elements. J. Phys. Chem. C 2016, 120, 8023-8032.

(59) Correa-Baena, J.P.; Turren-Cruz, S.H.; Tress, W.; Hagfeldt, A.; Aranda, C.; Shooshtari, L.; Bisquert, J.; Guerrero, A. Change from Bulk to Surface Recombination Mechanism between Pristine and Cycled Perovskite Solar Cells. ACS Energy Lett. 2017, 2, 681-688.

(60) Zhu, T.; Zheng, D.; Liu, J.; Coolen, L.; Pauporté, T. Electrical Response of High Efficiency and Stable Solar Cells Based on MACl Mediated Grown FA ${ }_{0.94} \mathrm{MA}_{0.06} \mathrm{PbI}_{3}$ Perovskite. ACS Appl. Mater. Interfaces 2020, 12, 37197-37207 
(61) Brug, G.J.; Van Der Eeden, A.L.G.; Sluyters-Rehbach, M.; Sluyters, J.H. The Analysis of Electrode Impedance Complicated by the Presence of a Constant Phase Element. J. Electroanal. Chem. 1984, 176, 275-295.

(62)Lee, J.W.; Dai, Z.; Han; T.H.; Choi, C.; Chang, S.Y.; Lee, S.J.; De Marco, N.; Zhao, H.; Sun, P.; Huang, Y.; Yang, Y. 2D Perovskite Stabilized Phase-Pure Formamidinium Perovskite Solar Cells. Nat. Commun. 2018, 9, 3021.

(63) Zhu, H.; Liu, Y.; Eickemeyer, F.T.; Pan, L.; Ren, D.; Ruiz, M.; Brian Carlsen, B.; Yang, B.; Wang, S.; Wang, Z.; Liu, H.; Zakeeruddin, S.M.; Hagfeldt, A.; Ibrahim Dar, M.; Li, X.; Grätzel, M. Tailored Amphiphilic Molecular Mitigators for Stable Perovskite Solar Cells with 23.5\% Efficiency. Adv. Mater. 2020, 1907757, 32 .

(64) Bi, D.; Tress, W.; Dar I.; Gao, P.; Luo,J.; Renevier, C.; Kurt Schenk, K.; Abate A.; Giordano, F.; Correa Baena, J.P.; Decoppet, J.D.; Zakeeruddin, S.M.; Nazeeruddin, M.K.; Grätzel, M.; Hagfeldt, A. Efficient Luminescent Solar Cells Based on Tailored Mixed-Cation Perovskites. Sci. Adv. 2016, 2:e1501170. 
D. Zheng, T. Zhu, Th. Pauporté ACS Appl. Energy Mater. (2020) DOI/10.1021/acsaem.0c00884

TOC
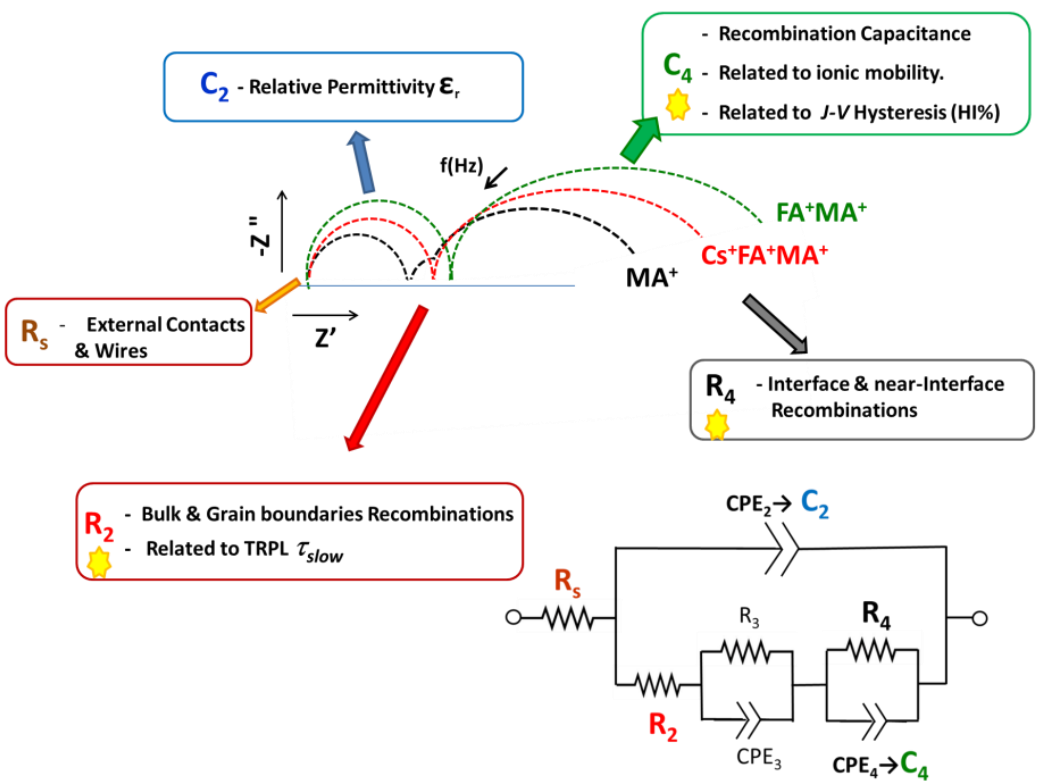